\title{
Disponibilidade domiciliar de alimentos no Brasil: \\ distribuição, composição nutricional, evolução e relação entre macronutrientes
}

Renata Bertazzi Levy

Tese apresentada ao Programa de Pós-Graduação em Saúde Pública para obtenção de título de Doutor em Saúde Pública.

Área de Concentração: Nutrição

Orientador: Prof. Tit. Carlos Augusto Monteiro

SÃO PAULO

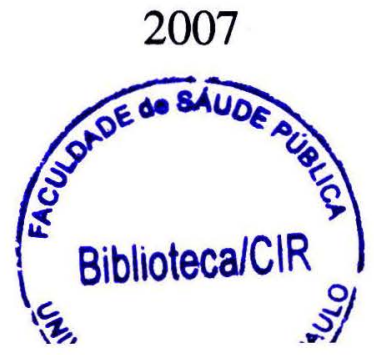


É expressamente proibida a comercialização deste documento tanto na sua forma impressa como eletrônica. Sua reprodução total ou parcial é permitida exclusivamente para fins acadêmicos e científicos, desde que na reprodução figure a identificação do autor, título, instituição e ano da tese.

$$
49324 \mid 2008 \text { dre }
$$


Aos meus pais e meus filhos, Leonardo e Giulia,com muito carinho e todo o meu amor. 


\section{AGRADECIMENTOS}

Ao meu orientador Prof. Carlos Augusto Monteiro, pela impecável orientação, pela dedicação, amizade e companheirismo na elaboração deste trabalho, me incentivando nos momentos difíceis com seu espírito empreendedor.

Ao amigo e parceiro, Rafael Claro, pela ajuda inestimável na construção dos bancos de dados, não se furtando a contribuir exaustivamente para o refinamento dos dados.

Ao amigo Wolney Lisboa Conde pela sua constante prontidão em me auxiliar nos momentos difíceis, sempre me ajudando a superar os diversos óbices à consecução desta tese.

Ao Humberto Lima, pelas preciosas contribuições dadas, pelo incentivo constante, compartilhando ao meu lado, os bons e maus momentos desse longo caminho.

Á querida Regina Rodrigues, pela gentileza e disposição em ajudar sempre que foi preciso e pela diagramação da tese.

As minhas companheiras de trabalho, Silvia Saldiva, Lenise Mondini e Sonia Venancio, que com incalculável presteza se sobrecarregaram no trabalho e sempre se mostraram compreensivas com as minhas ausências para elaborar esta tese.

As minhas amigas, Tereza Rosa pela pronta disposição em apresentar sugestões ao modelo, e a Patrícia Nery pela inesgotável determinação em ler esta tese e apresentar sugestões de escrita.

Ao Instituto Brasileiro de Geografia e Estatística pela valiosa oportunidade em etapa do trabalho desenvolvido em conjunto e esclarecimentos de informações referentes à pesquisa.

A minha mãe meu especial agradecimento pelo carinho, incentivo, suporte e presteza, sobretudo amparando meus filhos nos momentos em que precisei me dedicar à conclusão desta tese o tempo que seria dedicado aos meus filhos.

Finalmente, meu especial agradecimento aos meus filhos, Leonardo e Giulia, pela compreensão nos momentos de ausência em função da elaboração desta tese. 


\section{RESUMO}

Levy RB, Monteiro CA. Disponibilidade domiciliar de alimentos no Brasil: distribuição, composição nutricional, evolução e relação entre macronutrientes. São Paulo; 2007 [Tese de doutorado - Faculdade de Saúde Pública da USP].

Objetivo: Descrever a distribuição, composição nutricional e evolução da disponibilidade domiciliar de alimentos no Brasil e avaliar potenciais efeitos das calorias provenientes de açúcar sobre o consumo total de calorias e sobre o perfil de macronutrientes na dieta. Alcançaremos esse objetivo por meio da elaboração de três artigos. Métodos: Utilizaram-se dados sobre aquisição de alimentos coletados pela Pesquisa de Orçamentos Familiares POF, realizada entre junho de 2002 e julho de 2003 pelo IBGE em uma amostra probabilística de 48.470 domicílios do país. Para o estudo da evolução utilizaram-se dados coletados por POFs realizadas em 1974/75, 1986/87 e 1995/96 nas áreas metropolitanas do País. O padrão da disponibilidade domiciliar de alimentos foi descrito a partir da participação relativa de alimentos e macronutrientes segundo características sócio-demográficas dos domicílios. A influência da aquisição de açúcar sobre o consumo total de calorias e o perfil em macronutrientes da dieta foi estudada por meio de modelos de regressão linear múltipla. Resultados: Em todas as regiões e estratos de renda do País, a disponibilidade domiciliar de alimentos se mostrou adequada com relação ao teor protéico, com elevado aporte de proteína de origem animal, entretanto, insuficiente quanto à participação de frutas e hortaliças e excessiva no caso do açúcar. Nas regiões economicamente mais desenvolvidas e nos estratos de maior renda evidenciou-se participação excessiva de gorduras totais e gorduras saturadas. A evolução da participação de alimentos e macronutrientes na disponibilidade de alimentos nas áreas metropolitanas identificou declínio de alimentos básicos, elevação de alimentos processados, persistência de valores insuficientes para frutas e hortaliças e excessivos para açúcar e aumento do teor de gorduras totais e gorduras saturadas. Observou-se associação positiva e significativa entre aquisição de calorias provenientes de açúcar e valor calórico total da aquisição domiciliar de alimentos. Na condição de ausência de gasto com alimentação fora de casa, verificou-se que os níveis atuais de aquisição de açúcar determinam aquisição total de calorias que excedem as recomendações para ingestão calórica da população brasileira. Calorias adquiridas de açúcar aumentam significativamente a participação de gorduras na disponibilidade domiciliar de alimentos 
e diminuem, também significativamente, a participação de proteínas. Calorias de açúcar procedentes de alimentos processados aumentam significativamente a participação de gorduras e ácidos graxos saturados e diminuem, também significativamente, a participação de outros carboidratos que não 0 açúcar. Conclusões: Padrões e tendências da disponibilidade domiciliar de alimentos no Brasil são consistentes com a importância crescente de doenças crônicas não transmissíveis no perfil de morbi-mortalidade e com o aumento contínuo da prevalência de obesidade no País. Os resultados encontrados, relativos à influência do açúcar sobre o valor calórico total e o perfil em macronutrientes da disponibilidade domiciliar de alimentos corroboram orientações brasileiras e internacionais que recomendam a redução do consumo deste alimento e estipulam limites máximos para sua participação na dieta.

Descritores: Pesquisas de Orçamentos Familiares, padrão alimentar, disponibilidade de açúcar, qualidade da dieta. 


\section{ABSTRACT}

Levy RB, Monteiro CA. Household food availability in Brazil: distribution, nutritional composition, evolution and relation between macronutrients. São Paulo; 2007 [Doctoral dissertation

- School of Public Health, University of Sao].

Objectives: To describe the distribution of household food availability in Brazil and to evaluate the effect of sugar's availability (table sugar or sugar from process food) over total energy availability and macronutrient composition from household's Brazilians families. These objectives will be reaching by elaboration of tree different papers. Methods: The study uses food availability data from the "Pesquisa de Orçamentos Familiares - POF" budget survey conducted by the Brazilian Institute for Geography and Statistics from July 2002 to June 2003, including a probability national sample of 48,470 households. Food's availability patterns were described according to the amount of selected food groups and macronutrients relative to the household food's availability input over socio-demographics characteristics. The sugar's availability influence upon total energy availability and macronutrient composition were studied using multiple linear model regresses. Results: Adequate protein content and high proportion of animal protein, little availability of fruits and vegetables and excess calories from sugar were found in all regions and income layer around the country. An excessive proportion of calories from total and saturated fat around developed regions and higher-income families were evinced. Times-trends in metropolitan areas indicated a decline in the availability of basic foods and increases of processed foods, maintenance of little availability of fruit and vegetables, continuous increase in total and saturated fat and excessive proportion of sugar on food availability. Positive and significative association was observed between calories from sugar and household food availability. Over the condition of absence of food spent away from home, were verified that, the acquisition of sugar would bring the household food availability to excessive values front of the Brazilian's population recommendation. Sugar calories acquisition raises significantly the proportion of fat in household food availability and decrease, also significant, the proportion of protein. Calories from sugar proceeded from processed food increase significantly the proportion of total and saturated fat and decrease, also significant, the proportion of others carbohydrates minus sugar. Conclusions: Patterns and trends regarding household food availability are consistent with the increasing participation of chronic non-communicable diseases in 
morbidity and mortality and with the continuous increase in the prevalence of obesity in the country. The results found are in accordance with international and national propose that recommends the reduction of sugar consumption and suggests minimum value intake to guaranty a better quality of population's diet.

Keywords: Household budget survey, diet patterns, sugar's availability, quality diet. 


\section{ÍNDICE}

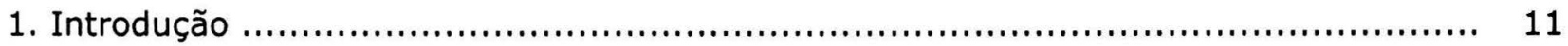

2. Artigo 1: Disponibilidade domiciliar de alimentos no Brasil: distribuição e evolução $(1974-2003)$

3. Artigo 2: Aquisição de açúcar e valor calórico total da disponibilidade domiciliar de alimentos no Brasil

4. Artigo 3: Efeito da aquisição de açúcar sobre o perfil em macronutrientes da disponibilidade domiciliar de alimentos (Brasil 2002-2003)

5. Considerações finais

6. Referências bibliográficas 


\section{LISTA DE TABELAS}

1. Artigo 1: Disponibilidade domiciliar de alimentos no Brasil: distribuição e evolução $(1974-2003)$

Tabela 1: Participação relativa (\%) de alimentos e grupos de alimentos no total de calorias determinado pela aquisição alimentar domiciliar por situação do domicílio. Brasil, 2002/2003

Tabela 2: Participação relativa (\%) de alimentos e grupos de alimentos no total de calorias determinado pela aquisição alimentar domiciliar por grandes regiões. Brasil, 2002/2003

Tabela 3: Participação relativa (\%) de alimentos e grupos de alimentos no total de calorias determinado pela aquisição alimentar domiciliar por faixas de renda mensal familiar per capita (em salários-mínimos). Brasil, $2002 / 2003$

Tabela 4: Participação relativa (\%) de macronutrientes no total de calorias determinado pela aquisição alimentar domiciliar por situação do domicílio, grandes regiões e classes de renda familiar per capita (em saláriosmínimos). Brasil, 2002/2003

Tabela 5: Evolução da participação relativa (\%) de alimentos e grupos de alimentos no total de calorias determinado pela aquisição alimentar domiciliar nas áreas metropolitanas e município de Goiânia. Brasil, 1974/1975 $2002 / 2003$

Tabela 6: Evolução da participação relativa (\%) de macronutrientes no total de calorias determinado pela aquisição alimentar domiciliar nas áreas metropolitanas e município de Goiânia. Brasil, 1974/1975 - 2002/2003 ....

2. Artigo 2: Aquisição de açúcar e valor calórico total da disponibilidade domiciliar de alimentos no Brasil

Tabela 1: Valor calórico total (VCT) da aquisição domiciliar de alimentos segundo a aquisição de calorias de açúcar em domicílios brasileiros (2002-2003) .......

Tabela 2: Médias do valor calórico total da aquisição de alimentos (VCT) e das calorias provenientes de açúcar segundo variáveis sócio-demográficas em domicílios brasileiros (2002-2003)

Tabela 3: Resultados do modelo final de regressão linear múltipla (sem interações) relativo à associação entre calorias adquiridas de açúcar e o valor calórico total da aquisição domiciliar de alimentos (kcal/per capita) em domicílios brasileiros (2002-2003) 
Tabela 4: Resultados do modelo final de regressão linear múltipla (com interação) relativo à associação entre calorias adquiridas de açúcar e o valor calórico total de aquisição domiciliar de alimentos (kcal/per capita) em domicílios brasileiros (2002-2003)

Figura 1: Estimativas de modelo de regressão linear múltiplo (com interação) para a relação entre aquisição de calorias de açúcar e valor calórico total (VCT) da aquisição domiciliar de alimentos no primeiro quintil, quintil intermediário e quinto quintil da distribuição da renda domiciliar per capita conforme dois cenários para o percentual do gasto em alimentação fora de casa. Brasil, 2002/2003

3. Artigo 3: Efeito da aquisição de açúcar sobre o perfil em macronutrientes da disponibilidade domiciliar de alimentos (Brasil 2002-2003)

Tabela 1: Valores médios para calorias provenientes de diferentes macronutrientes segundo quartis das calorias provenientes de açúcar na aquisição domiciliar de alimentos. Brasil, 2002/2003

Tabela 2: Coeficientes de regressão das calorias provenientes de açúcar sobre as calorias provenientes de outros macronutrientes na aquisição domiciliar de alimentos. Brasil 2002-2003

Tabela 3: Coeficientes de regressão ajustados das calorias provenientes de açúcar e suas frações sobre as calorias provenientes de outros macronutrientes na aquisição domiciliar de alimentos. Brasil 2002-2003 


\section{INTRODUÇÃO}

Dados de inquéritos nacionais, de base populacional, realizados no Brasil entre 1975 e 2003, evidenciam declínio contínuo da prevalência de déficits ponderais e avanço da prevalência de excesso de peso e obesidade, em todas as regiões do País e em todas as classes de renda (IBGE 2004, IBGE 2006, MONTEIRO et al 2007). Por outro lado, séries históricas de estatísticas de mortalidade, disponíveis para as capitais dos estados brasileiros, indicam que a proporção de mortes por doenças crônicas não transmissíveis, a maior parte delas relacionadas a desequilíbrios na dieta e à obesidade (WHO2003), aumentou em mais de três vezes entre as décadas de 1930 e 1990 (MALTA et al).

Para estudiosos do fenômeno da transição nutricional nos países em desenvolvimento, a trajetória dos indicadores nutricionais descritos no Brasil se deve a mudanças na composição das dietas e no estilo de vida dos indivíduos decorrentes de mudanças no ambiente relacionadas à industrialização, urbanização e integração daqueles países à economia global (POPKIN 2002). 
O acúmulo de evidências que indicam que determinadas características da dieta aumentam substancialmente o risco de doenças cardiovasculares, certos tipos de câncer, obesidade, dislipidemias e diabetes, entre outras, contribuiu para a decisão da Organização Mundial Saúde (OMS) em estabelecer limites máximos de consumo para a ingestão de gorduras ( $30 \%$ do valor calórico total), ácidos graxos saturados ( $10 \%$ do consumo calórico total), colesterol (300 mg dia) e açúcar (10\% do valor calórico total) e limites mínimos para o consumo de frutas e hortaliças $(400 \mathrm{~g}$ por dia) e carboidratos complexos (entre 55 e $75 \%$ do valor calórico total) (WHO/FAO 2003).

Embora a recomendação da OMS em limitar o consumo de açúcar não tenha sido adotada por todos os países - nos EUA e Canadá, por exemplo, o limite superior para a participação do açúcar nas calorias totais é de $25 \%$ (IOM 2002) - A redução no consumo de açúcar encontra suporte em vários estudos que associam o consumo deste alimento a efeitos desfavoráveis para a saúde. Dentre esses efeitos destacam-se o aumento na ocorrência de cárie dental (WHO/FAO 2003), o consumo excessivo de calorias (KRANZ et al 2005, POPKIN and NIELSEN 2003, MANN 2004) ou ganho excessivo de peso (LUDWIG et al 2001, DUBOIS et al 2007), aumento na incidência de doenças cardiovasculares (FRIED and 
RAO 2003) e diabetes (KELLEY 2003), as alterações desfavoráveis na composição da dieta em macronutrientes, em particular diminuição da participação de proteínas (FARRIS 1998, KRANZ et al 2005) e diluição na concentração da oferta de micronutrientes na dieta (POPKIN and NIELSEN 2003, KRANZ et al 2005, UTE et al 2002).

Embora não se disponha de dados do consumo populacional, a evolução da disponibilidade de alimentos na América Latina, obtida por meio de folhas de balanço de alimentos, indica tendência de aumento na participação de gorduras na dieta, principalmente gordura de origem animal, e aumento da já elevada participação de calorias de açúcar na dieta. Entre 1970/72 e 1995/96 a participação do açúcar na disponibilidade de alimentos dos países latinoamericanos aumentou de $15,8 \%$ para $16,9 \%$ (BERMUDEZ and TUCKER 2003). No Brasil a evolução da disponibilidade nacional de alimentos entre 1961/63 e 1999/2001, considerada esta mesma fonte, aponta grande aumento na participação de gorduras (de $15,7 \%$ para $26,3 \%$ das calorias totais) e aumento na já elevada participação de açúcar (de 18,0 para 18,8 das calorias totais) (MONTEIRO et al 2007, FAOSTAT 2004). Evolução do padrão de disponibilidade de alimentos das famílias brasileiras residentes em áreas metropolitanas pode ser 
conhecida a partir das Pesquisas de Orçamentos Familiares (POF) realizadas pelo Instituto Brasileiro de Geografia e Estatística (IBGE). Análise das POF realizadas em 1986/87 e 1995/96, evidenciou aumento na disponibilidade domiciliar de açúcar e diminuição de frutas e hortaliças (MONTEIRO et al 2000). A participação do açúcar no total calórico da aquisição de alimentos excedeu o limite máximo de $10 \%$ nas duas pesquisas (MONTEIRO et al 2000).

O objetivo central deste trabalho é descrever o padrão e a evolução da aquisição de alimentos no país e avaliar potenciais efeitos da aquisição de açúcar sobre indicadores da qualidade da dieta da população brasileira, em particular sobre o valor calórico total da dieta e sobre seu teor em gorduras totais, ácidos graxos saturados, proteínas e carboidratos que não o açúcar. Esse objetivo será alcançado por meio da elaboração de três artigos que utilizam dados das Pesquisas de Orçamentos Familiares realizadas pelo IBGE. Cada artigo comporta objetivos específicos e metodologia própria. 
2. ARTIGO 1

Disponibilidade domiciliar de alimentos no Brasil: distribuição e evolução (1974-2003). 


\title{
Disponibilidade domiciliar de alimentos no Brasil: distribuição e evolução (1974-2003) Household food availability in Brazil: distribution and trends (1974-2003)
}

\author{
Renata Bertazzi Levy-Costa ${ }^{a}$, Rosely Sichieri', Nézio dos Santos Pontes ${ }^{c}$ e Carlos Augusto \\ Monteiro ${ }^{\circ}$
}

a Núcleo de Investigação em Nutrição. Instituto de Saúde. Secretaria de Estado da Saúde de São Paulo. São Paulo, SP, Brasil. 'D Departamento de Epidemiologia. Instituto de Medicina Social. Universidade Estadual do Rio de Janeiro. Rio de Janeiro, RJ, Brasil. ${ }^{\circ}$ Coordenação de Indices de Preços. Pesquisa de Orçamentos Familiares. Instituto Brasileiro de Geografia e Estatistica (IBGE).Rio de Janeiro, RJ, Brasil. 'Departamento de Nutrição. Faculdade de Saúde Pública. Universidade de São Paulo. São Paulo, SP, Brasil

\section{Descritores}

Pesquisa de orçamento familiar. Consumo de alimentos. Inquéritos nutricionais. Dieta. Zonas metropolitanas. Renda familiar. Fatores socioeconômicos.

\section{Resumo}

\section{Objetivo}

Descrever a distribuição da disponibilidade domiciliar de alimentos no Brasil em 20022003 e avaliar sua evolução nas áreas metropolitanas do País no período 1974-2003.

\section{Métodos}

A principal base de dados do estudo é a Pesquisa de Orçamento Familiar de 2002 2003 realizada pelo Instituto Brasileiro de Geografia e Estatística em 48.470 domicílios brasileiros. Em cada domicílio, num período de sete dias consecutivos, foram registradas todas as aquisições, monetárias ou não monetárias, de alimentos e bebidas para consumo familiar. As quantidades de alimentos adquiridas foram transformadas em calorias e macronutrientes, usando tabelas de composição alimentar.

Resultados

Características positivas do padrão alimentar, encontradas em todas as regiões e em todas as classes de rendimento, foram a adequação do teor protéico das dietas e o elevado aporte relativo de proteínas de alto valor biológico. Caracteristicas negativas, também disseminadas no País, foram excesso de açúcar e presença insuficiente de frutas e hortaliças na dieta. Nas regiões economicamente mais desenvolvidas, no meio urbano e entre famílias com maior rendimento houve também excesso de gorduras em geral e de gorduras saturadas. A evolução nas áreas metropolitanas do País evidenciou declínio no consumo de alimentos básicos, como arroz e feijão, aumentos de até $400 \%$ no consumo de produtos industrializados, como biscoitos e refrigerantes, persistência do consumo excessivo de açúcar e insuficiente de frutas e hortaliças e aumento no teor da dieta em gorduras em geral e gorduras saturadas.

Conclusões

Padrões e tendências da disponibilidade domiciliar de alimentos no Brasil são consistentes com a importância crescente de doenças crônicas não transmissiveis no perfil de morbi-mortalidade e com o aumento contínuo da prevalência da obesidade no País.

\section{Keywords}

Household budget survey. Food consumption. Drinking. Diet.

\section{Abstract}

Objective

Data from household food budget surveys were examined in order to describe the

Recebido em 25/2/2005. Aprovado em 25/4/2005. 
Socio-economic factors.

regional and socio-economic distribution of household food availability in Brazil in 2002-2003 and trends from 1974 to 2003.

Methods

The study uses data from the "Pesquisa de Orçamento Familiar 2002-2003" budget survey conducted by the Brazilian Institute for Geography and Statistics (Instituto Brasileiro de Geografia e Estatistica) from July 2002 to June 2003, including a national sample of 48,470 households. In each household, during seven consecutive days, all monetary and non-monetary expenses with food and beverages for family consumption were registered. Crude weights of purchased foods were transformed into calories and nutrients with the use of food composition tables.

Results

Adequate protein content and a high proportion of animal protein were found in all regions and income strata. These were the most important positive aspects identified in the household food availability in Brazil. On the other hand, all regions and socioeconomic strata showed excess calories from sugar and little availability of fruits and vegetables. An excessive proportion of calories came from total and saturated fat in the more economically developed regions and in the urban milieu, as well as among higher-income families. Time-trends in metropolitan areas indicated a decline in the consumption of basic, traditional foods, such as rice and beans; notable increases (up to 400\%) in the consumption of processed food items, such as cookies and soft drinks; maintenance of the excessive consumption of sugar; and a continuous increase in total fat and saturated fat content in the diet.

Conclusions

Patterns and trends regarding household food availability in Brazil are consistent with the increasing participation of chronic non-communicable diseases in morbidity and mortality and with the continuous increase in the prevalence of obesity.

\section{INTRODUÇÃO}

A dieta inadequada e a inatividade física compõem um complexo de causas de grande importância para a saúde da população. Esses fatores se associam fortemente a muitas doenças crônicas não transmissíveis e altamente prevalentes, a exemplo da obesidade, diabetes tipo 2 e doença coronariana. ${ }^{23}$ Por outro lado, importante parcela das deficiências nutricionais, com destaque para a anemia ferropriva, tanto no Brasil quanto no mundo, também tem na dieta seu principal fator etiológico. Como a dieta é passível de modificação, torna-se necessário o desenvolvimento de políticas para a prevenção, tanto das deficiências nutricionais, quanto das doenças crônicas não transmissíveis. Essa modificação deve ter por base a existência de sistemas que monitorem, de preferência com fluxos de informações já existentes, indicadores do consumo alimentar. Pesquisas de Orçamento Familiar (POF) constituem fonte valiosa para obtenção de indicadores do consumo alimentar, cujo uso é crescente em países em desenvolvimento. ${ }^{16,20}$

O Brasil tem realizado POF com alguma regularidade em suas áreas metropolitanas e por meio delas têm sido avaliada a tendência secular de disponibilidade domiciliar de alimentos no País. ${ }^{10,11}$ As POF não permitem avaliar o consumo individual, mas ocupam posição intermediária entre as folhas de balanço de ali- mentos, que descrevem a disponibilidade nacional de alimentos, e os inquéritos desenhados para avaliação do consumo individual. Embora o principal objetivo das POF seja o de estimar índices de preços, elas representam importante fonte de dados da dieta na medida em que empregam metodologia padronizada de coleta de dados, utilizam amostragem probabilística, são periódicas e incluem detalhada mensuração de características socioeconômicas. ${ }^{8}$

O presente estudo busca descrever a distribuição regional e socioeconômica da disponibilidade domiciliar de alimentos no País e avaliar a evolução dessa disponibilidade nas últimas três décadas, com base no banco de dados nacionais da POF brasileira realizada em 2002/2003 5 e nos bancos de dados relativos às áreas metropolitanas das POF realizadas em meados das décadas de 70,80 e $90 .^{4}$

\section{MÉTODOS}

A POF de 2002-2003 foi realizada entre julho de 2002 a junho de 2003 e envolveu entrevistas realizadas numa amostra de 48.470 domicílios. O plano de amostragem da pesquisa, semelhante ao adotado pelo Instituto Brasileiro de Geografia e Estatística (IBGE) em pesquisas de orçamento familiar anteriores, é detalhadamente descrito em outra publicação. ${ }^{5}$ Em resumo, trata-se de amostragem por conglomerado, em 
dois estágios, com estratificação geográfica e socioeconômica das unidades primárias de amostragem, correspondentes aos setores censitários da base geográfica do Censo Demográfico 2000. As unidades secundárias de amostragem foram os domicílios particulares permanentes no setor. Os setores censitários foram selecionados por amostragem sistemática com probabilidade proporcional ao número de domicílios no setor, enquanto os domicílios foram selecionados por amostragem aleatória simples, sem reposição, dentro dos setores censitários sorteados. Os setores sorteados e respectivos domicílios selecionados foram distribuídos ao longo de 12 meses de duração da pesquisa, garantindo-se em todos os trimestres a coleta de dados em todos os estratos geográficos e socioeconômicos. A amostragem da POF 2002-2003 foi estruturada para produzir estimativas representativas do País como um todo, de suas grandes regiões (Norte, Nordeste, Sudeste, Sul e Centro-Oeste) e de todas as unidades da Federação. No caso do País e das grandes regiões, a amostra permite estimativas representativas para domicílios na situação urbana e na situação rural.

A informação básica da POF analisada compreende as aquisições de alimentos e bebidas para consumo domiciliar feitas pela unidade de consumo (família) durante um período de sete dias consecutivos e registradas diariamente pelo morador do domicílio ou pelo entrevistador do IBGE numa caderneta. No registro incluem-se a descrição detalhada do produto, a quantidade adquirida e a unidade de medida, além do valor da despesa em Reais, local de compra e forma de aquisição (monetária ou não). A POF 20022003 envolveu o registro de aproximadamente 820 mil aquisições de alimentos e bebidas para consumo domiciliar. Em cerca de $80 \%$ das aquisições foi possível apurar diretamente a quantidade em quilograma ou litro do produto adquirido, sendo que, nos demais casos, a quantidade foi imputada com base no valor da despesa e do preço médio do produto.

Os indicadores empregados incluem a média do valor calórico total da disponibilidade alimentar domiciliar (expressa em kcal per capita por dia) e a participação relativa, na disponibilidade alimentar de alimentos, grupos de alimentos e nutrientes selecionados.

Para transformação das quantidades brutas de alimentos em calorias e macronutrientes procedeu-se previamente ao agrupamento de produtos semelhantes e com participação pouco expressiva no conjunto das aquisições (por exemplo, ervilha, lentilha e grão de bico foram agrupados em "outras leguminosas") o que resultou numa lista reduzida de 214 itens ali- mentares. No caso de itens compostos por mais de um alimento, considerou-se a composição nutricional do alimento com maior participação no item. A transformação foi iniciada aplicando-se às quantidades brutas dos alimentos fatores de correção que excluem as partes não comestíveis dos alimentos. ${ }^{3} \mathrm{~A}$ seguir, para se chegar às quantidades disponíveis de calorias e macronutrientes, foram utilizadas três tabelas de composição alimentar: a tabela TACO (Tabela Brasileira de Composição de Alimentos); ${ }^{14}$ a tabela Guilherme Franco ${ }^{2}$ e a tabela IBGE/Estudo Nacional de Despesa Familiar (ENDEF). ${ }^{3}$ A tabela TACO foi utilizada para todos os alimentos de origem animal, com exceção de embutidos, para os quais se utilizou a tabela Guilherme Franco. Para todos os demais alimentos foi utilizada a tabela IBGE/ENDEF. Adicionalmente, no caso específico da composição em ácidos graxos, não constantes das tabelas Guilherme Franco e IBGE/ ENDEF, foram utilizadas tabelas americanas de composição alimentar. ${ }^{19}$

Para descrição da participação relativa de alimentos e grupos de alimentos na disponibilidade total de alimentos das famílias, os 214 itens alimentares foram reagrupados em 48 itens. A seguir, foram classificados em 15 grupos: três grupos de alimentos básicos de origem vegetal, fontes de energia e, em diferentes proporções, também, de proteína, micronutrientes e fibras (cereais e derivados, feijões e outras leguminosas e raízes, tubérculos e derivados); três grupos de alimentos de origem animal, fontes simultâneas de energia, proteína, gordura (sobretudo gordura saturada) e micronutrientes (carnes e derivados, leite e derivados e ovos); dois grupos de alimentos de origem vegetal, de baixa densidade energética, e ri$\cos$ em micronutrientes e fibras (frutas e sucos naturais e legumes e verduras); quatro grupos de alimentos essencialmente calóricos (óleos e gorduras vegetais, gorduras animais, açúcar e refrigerantes e bebidas alcoólicas) e três grupos adicionais de alimentos com participação menos expressiva na alimentação da população brasileira (oleaginosas, condimentos e refeições prontas e misturas industrializadas).

$\mathrm{O}$ aporte relativo de nutrientes na disponibilidade alimentar considerou apenas a contribuição de macronutrientes, ou seja, carboidratos (subdivididos em açúcar [sacarose] e demais carboidratos), proteínas (subdivididas conforme a origem animal ou vegetal) e lipídios (subdivididos em ácidos graxos mono-insaturados, poli-insaturados e saturados). Tanto no caso dos alimentos quanto no caso dos macronutrientes, a participação relativa na disponibilidade alimentar familiar foi expressa a partir do percentual de calorias que o alimento ou o macronutriente representava no total de calorias disponíveis para consumo. 
Estimativas sobre o valor calórico da disponibilidade domiciliar de alimentos e sobre a participação relativa de alimentos, grupos de alimentos e nutrientes naquele valor calórico foram fornecidas segundo a situação do domicílio (urbana ou rural), as cinco grandes regiões e as classes de renda. As classes de renda consideradas abrangem desde familias com rendimentos mensais de até um quarto de salário-mínimo per capita (os 5,8\% de famílias de menores rendimentos) até famílias com rendimentos mensais superiores a cinco salários-mínimos per capita (os 4,2\% de famílias de maiores rendimentos).

As estimativas da POF 2002-2003 para o conjunto das áreas metropolitanas do País foram comparadas às estimativas calculadas a partir de pesquisas de orça- mento familiar realizadas pelo IBGE em 1974/75, 1986/ 87 e 1995/96. Esse conjunto inclui as áreas metropolitanas de Belém, Fortaleza, Salvador, Belo Horizonte, Rio de Janeiro, São Paulo, Curitiba e Porto Alegre, Distrito Federal e o município de Goiânia. Procedimentos idênticos aos empregados pela POF 2002-2003 foram empregados nas demais pesquisas para gerar os indicadores da disponibilidade alimentar.

Todas as estimativas levaram em conta os fatores de expansão das pesquisas de orçamento familiar bem como a complexidade do desenho amostral das mesmas.

A avaliação da adequação nutricional da composição da disponibilidade domiciliar de alimentos to-

Tabela 1 - Participaçăo relativa (\%) de alimentos e grupos de alimentos no total de calorias determinado pela aquisição alimentar domiciliar por situaçăo do domicrlio. Brasil, 2002/2003.

\begin{tabular}{|c|c|c|c|}
\hline Grupos de alimentos & Total & $\begin{array}{c}\text { Situaçăo do domićlío } \\
\text { Urbano }\end{array}$ & Rural \\
\hline $\begin{array}{l}\text { Cereais e derivados } \\
\text { Arroz polido } \\
\text { Pao frances } \\
\text { Biscoitos } \\
\text { Macarráo } \\
\text { Farinha de trigo } \\
\text { Outros } \\
\text { Feijoes e outras leguminosas } \\
\text { Raizes, tuberculos e derivados } \\
\text { Batata } \\
\text { Mandioca } \\
\text { Outros } \\
\text { Carnes } \\
\text { Bovina } \\
\text { Frango } \\
\text { Suina } \\
\text { Peixes } \\
\text { Embutidos } \\
\text { Outras } \\
\text { Leites e derivados } \\
\text { Leite } \\
\text { Queijos } \\
\text { Outros } \\
\text { Ovos } \\
\text { Frutas e sucos naturais } \\
\text { Bananas } \\
\text { Laranjas } \\
\text { Outras } \\
\text { Verduras e legumes } \\
\text { Tomate } \\
\text { Outros } \\
\text { Oleos e gorduras vegetais } \\
\text { Oleo de soja } \\
\text { Margarina } \\
\text { Outros } \\
\text { Gordura animal } \\
\text { Manteiga } \\
\text { Toucinho } \\
\text { Açúcar e refrigerantes } \\
\text { Açucar } \\
\text { Refrigerantes } \\
\text { Bebidas alcoolicas } \\
\text { Cerveja } \\
\text { Aguardente } \\
\text { Outras } \\
\text { Oleaginosas } \\
\text { Condimentos } \\
\text { Refeiçoes prontas e misturas in } \\
\end{array}$ & $\begin{array}{c}36,4 \\
17,8 \\
5,5 \\
3,1 \\
2,7 \\
2,8 \\
4,6 \\
6,6 \\
5,8 \\
0,7 \\
0,4 \\
4,6 \\
11,8 \\
5,1 \\
2,5 \\
1,2 \\
0,6 \\
2,2 \\
0,1 \\
6,3 \\
4,6 \\
1,1 \\
0,6 \\
0,3 \\
1,6 \\
0,7 \\
0,2 \\
0,8 \\
0,7 \\
0,2 \\
0,6 \\
12,8 \\
10,5 \\
1,8 \\
0,5 \\
1,3 \\
0,4 \\
1,0 \\
13,4 \\
11,9 \\
1,5 \\
0,5 \\
0,3 \\
0,1 \\
0,1 \\
0,2 \\
\end{array}$ & $\begin{array}{c}36,4 \\
17,3 \\
6,5 \\
3,3 \\
2,9 \\
2,5 \\
3,9 \\
5,8 \\
4,3 \\
0,8 \\
0,2 \\
3,3 \\
12,3 \\
5,4 \\
2,7 \\
1,1 \\
0,5 \\
2,5 \\
0,1 \\
6,7 \\
4,6 \\
1,3 \\
0,7 \\
0,3 \\
1,8 \\
0,7 \\
0,2 \\
0,9 \\
0,8 \\
0,2 \\
0,6 \\
13,5 \\
10,9 \\
2,1 \\
0,6 \\
1,2 \\
0,4 \\
0,8 \\
13,4 \\
11,7 \\
1,7 \\
0,5 \\
0,4 \\
0,1 \\
0,1 \\
0,1 \\
0,7 \\
2,0 \\
\end{array}$ & $\begin{array}{c}36,3 \\
19,3 \\
1,9 \\
2,4 \\
2,0 \\
3,8 \\
6,8 \\
9,0 \\
10,6 \\
0,6 \\
0,9 \\
9,2 \\
10,0 \\
4,1 \\
1,8 \\
1,7 \\
1,0 \\
1,1 \\
0,3 \\
5,1 \\
4,4 \\
0,5 \\
0,1 \\
0,5 \\
0,9 \\
0,4 \\
0,1 \\
0,3 \\
0,5 \\
0,1 \\
0,4 \\
10,4 \\
9,3 \\
0,8 \\
0,3 \\
1,8 \\
0,2 \\
1,7 \\
13,3 \\
12,8 \\
0,6 \\
0,2 \\
0,1 \\
0,1 \\
0,0 \\
0,4 \\
0,3 \\
0,9 \\
\end{array}$ \\
\hline Total & 100,0 & 100,0 & 100,0 \\
\hline Total de calorias (kcal/dia per & 1.811 & 1.690 & 2.402 \\
\hline
\end{tabular}


mou por base recomendações nutricionais recentes formuladas por agências das Nações Unidas. ${ }^{23}$

\section{RESULTADOS}

A disponibilidade domiciliar média de alimentos no Brasil foi estimada em $1.800 \mathrm{kcal}$ por pessoa por dia, sendo essa disponibilidade próxima de $1.700 \mathrm{kcal}$ no meio urbano e de $2.400 \mathrm{kcal}$ no meio rural (Tabela 1). Ressalve-se que não é possível avaliar a adequação dessa disponibilidade calórica, uma vez que não se dispõe de uma avaliação direta dos alimentos efetivamente consumidos pelas famílias, bem como das quantidades de alimentos consumidos fora do domicílio.

A Tabela 1 mostra a participação relativa de ali- mentos e grupos de alimentos na disponibilidade alimentar domiciliar. Os alimentos básicos de origem vegetal (cereais, leguminosas e raízes e tubérculos) correspondem a cerca de $50 \%$ das calorias totais, vindo, a seguir, com cerca de $28 \%$, os alimentos essencialmente calóricos (óleos e gorduras vegetais, gordura animal, açúcar e refrigerantes e bebidas alcoólicas) e, com cerca de $18 \%$, os produtos de origem animal (carnes, leite e derivados e ovos). Frutas, verduras e legumes correspondem a apenas $2,3 \%$ das calorias totais, ou cerca de um terço das recomendações para o consumo desses alimentos (pelo menos 400 gramas diárias ou cerca de 6-7\% das calorias totais de uma dieta de $2.300 \mathrm{kcal}$ diárias, valor calórico diário correspondente à necessidade energética média diária estimada pela Food

Tabela 2 - Participaçăo relativa (\%) de alimentos e grupos de alimentos no total de calorias determinado pela aquisiçăo alimentar domiciliar por grandes regioes. Brasil, 2002/2003.

\begin{tabular}{|c|c|c|c|c|c|}
\hline Grupos de alimentos & Norte & Nordeste & $\begin{array}{c}\text { Grandes regióes } \\
\text { Sul }\end{array}$ & Sudeste & Centro-Oeste \\
\hline $\begin{array}{l}\text { Cereais e derivados } \\
\text { Arroz polido } \\
\text { Pao frances } \\
\text { Biscoitos } \\
\text { Macarráo } \\
\text { Farinha de trigo } \\
\text { Outros } \\
\text { Feijoes e outras leguminosas } \\
\text { Raizes, tuberculos e derivados } \\
\text { Batata } \\
\text { Mandioca } \\
\text { Outros } \\
\text { Carnes } \\
\text { Bovina } \\
\text { Frango } \\
\text { Suina } \\
\text { Peixes } \\
\text { Embutidos } \\
\text { Outras } \\
\text { Leites e derivados } \\
\text { Leites } \\
\text { Queijos } \\
\text { Outros } \\
\text { Ovos } \\
\text { Frutas e sucos naturais } \\
\text { Bananas } \\
\text { Laranjas } \\
\text { Outras } \\
\text { Verduras e legumes } \\
\text { Tomate } \\
\text { Outros } \\
\text { Oleos e gorduras vegetais } \\
\text { Oleo de soja } \\
\text { Margarina } \\
\text { Outros } \\
\text { Gordura animal } \\
\text { Manteiga } \\
\text { Toucinho } \\
\text { Açúcar e refrigerantes } \\
\text { Açucar } \\
\text { Refrigerantes } \\
\text { Bebidas alcoolicas } \\
\text { Cerveja } \\
\text { Aguardente } \\
\text { Outras } \\
\text { Oleaginosas } \\
\text { Condimentos } \\
\text { Refeiçoes prontas e misturas industrializadas } \\
\end{array}$ & $\begin{array}{c}29,6 \\
17,6 \\
4,5 \\
2,2 \\
1,7 \\
1,2 \\
2,4 \\
5,0 \\
19,3 \\
0,3 \\
0,6 \\
18,4 \\
14,9 \\
6,5 \\
2,9 \\
0,9 \\
3,1 \\
1,1 \\
0,5 \\
3,7 \\
3,1 \\
0,3 \\
0,3 \\
0,5 \\
1,2 \\
0,7 \\
0,1 \\
0,4 \\
0,5 \\
0,1 \\
0,4 \\
10,9 \\
9,3 \\
1,4 \\
0,2 \\
0,7 \\
0,4 \\
0,3 \\
10,8 \\
9,9 \\
0,9 \\
0,2 \\
0,1 \\
0,0 \\
0,0 \\
1,7 \\
0,3 \\
1,0 \\
\end{array}$ & $\begin{array}{c}36,7 \\
17,7 \\
5,3 \\
4,0 \\
2,8 \\
0,8 \\
6,1 \\
9,4 \\
10,1 \\
0,4 \\
0,3 \\
9,4 \\
10,9 \\
5,9 \\
2,2 \\
0,6 \\
0,7 \\
1,2 \\
0,2 \\
4,4 \\
3,4 \\
0,6 \\
0,3 \\
0,4 \\
1,2 \\
0,5 \\
0,1 \\
0,5 \\
0,7 \\
0,2 \\
0,5 \\
10,4 \\
8,1 \\
2,0 \\
0,3 \\
0,7 \\
0,4 \\
0,3 \\
13,6 \\
12,7 \\
0,8 \\
0,2 \\
0,1 \\
0,1 \\
0,0 \\
0,1 \\
0,3 \\
1,1 \\
\end{array}$ & $\begin{array}{c}37,0 \\
13,3 \\
4,8 \\
2,9 \\
2,9 \\
9,1 \\
4,1 \\
4,6 \\
2,6 \\
1,2 \\
0,7 \\
0,7 \\
14,3 \\
5,9 \\
2,8 \\
2,5 \\
0,2 \\
2,7 \\
0,1 \\
7,5 \\
5,5 \\
1,3 \\
0,8 \\
1,0 \\
1,9 \\
0,7 \\
0,3 \\
0,9 \\
0,7 \\
0,1 \\
0,6 \\
12,1 \\
9,3 \\
1,8 \\
0,9 \\
2,2 \\
0,1 \\
2,0 \\
12,2 \\
10,4 \\
1,8 \\
0,7 \\
0,4 \\
0,1 \\
0,2 \\
0,1 \\
0,9 \\
2,3 \\
\end{array}$ & $\begin{array}{c}36,9 \\
18,3 \\
6,2 \\
2,9 \\
2,9 \\
2,1 \\
4,5 \\
5,9 \\
2,2 \\
0,9 \\
0,3 \\
1,0 \\
11,1 \\
4,0 \\
2,6 \\
1,1 \\
0,3 \\
2,9 \\
0,1 \\
7,6 \\
5,2 \\
1,6 \\
0,8 \\
0,0 \\
1,9 \\
0,7 \\
0,2 \\
0,9 \\
0,8 \\
0,2 \\
0,6 \\
14,4 \\
12,0 \\
1,8 \\
0,6 \\
1,6 \\
0,4 \\
1,2 \\
14,2 \\
12,3 \\
1,9 \\
0,6 \\
0,4 \\
0,1 \\
0,1 \\
0,0 \\
0,8 \\
2,1 \\
\end{array}$ & $\begin{array}{c}38,7 \\
26,2 \\
4,0 \\
2,1 \\
2,1 \\
2,3 \\
2,0 \\
5,5 \\
1,9 \\
0,4 \\
0,4 \\
1,1 \\
10,6 \\
5,2 \\
2,3 \\
1,2 \\
0,2 \\
1,6 \\
0,1 \\
6,6 \\
5,3 \\
0,8 \\
0,5 \\
0,5 \\
1,2 \\
0,5 \\
0,2 \\
0,6 \\
0,7 \\
0,2 \\
0,5 \\
17,0 \\
15,4 \\
1,4 \\
0,2 \\
1,2 \\
0,3 \\
0,9 \\
13,7 \\
12,3 \\
1,4 \\
0,5 \\
0,4 \\
0,1 \\
0,1 \\
0,0 \\
0,5 \\
1,4 \\
\end{array}$ \\
\hline Total & 100.0 & 100,0 & 100,0 & 100,0 & 100,0 \\
\hline Total de calorias (kcal/dia per capita) & 1.884 & 1.761 & 1.984 & 1.787 & 1.714 \\
\hline
\end{tabular}


and Agriculture Organization (FAO) para a população brasileira. ${ }^{15}$

A importância na dieta de cereais e derivados foi semelhante nas áreas urbanas e rurais do Pais, havendo maior participação de pão, biscoitos e macarrão no meio urbano e no meio rural, maior a participação de arroz e farinha de trigo. Maior participação na dieta de frutas, verduras e legumes, carnes e leite e derivados foi encontrada no meio urbano, enquanto no meio rural foi maior a participação de feijões e outras leguminosas e de raizes e tubérculos. A participação na dieta de refeições prontas e misturas industrializadas foi três vezes maior no meio urbano do que no meio rural (Tabela 1).

Perfis diferenciados da disponibilidade domiciliar de alimentos caracterizam as cinco grandes regiões do País (Tabela 2). Observa-se que a participação do arroz na disponibilidade alimentar da região CentroOeste e a participação da farinha de trigo na região Sul excedem em uma e meia a duas vezes e em quatro a dez vezes, respectivamente, a mesma participação observada nas demais regiões. Situações semelhantes são vistas com relação a feijões e biscoitos na região Nordeste, a farinha de mandioca nas regiões Norte e Nordeste, a carnes nas regiões Norte e Sul, a peixes na região Norte e carne suína na região Sul, a frutas e sucos naturais nas regiões Sul e Sudeste, a óleo de soja na região Centro-Oeste, a toucinho na região Sul, a refrigerantes, bebidas alcoólicas, condimentos e refeições prontas nas regiões Sul e Sudeste e a oleaginosas (castanha do Pará) na região Norte.

Tabela 3 - Participaçáo relativa (\%) de alimentos e grupos de alimentos no total de calorias determinado pela aquisiçáo alimentar domiciliar por faixas de renda mensal familiar per capita (em salários-mínimos). Brasil, 2002/2003.

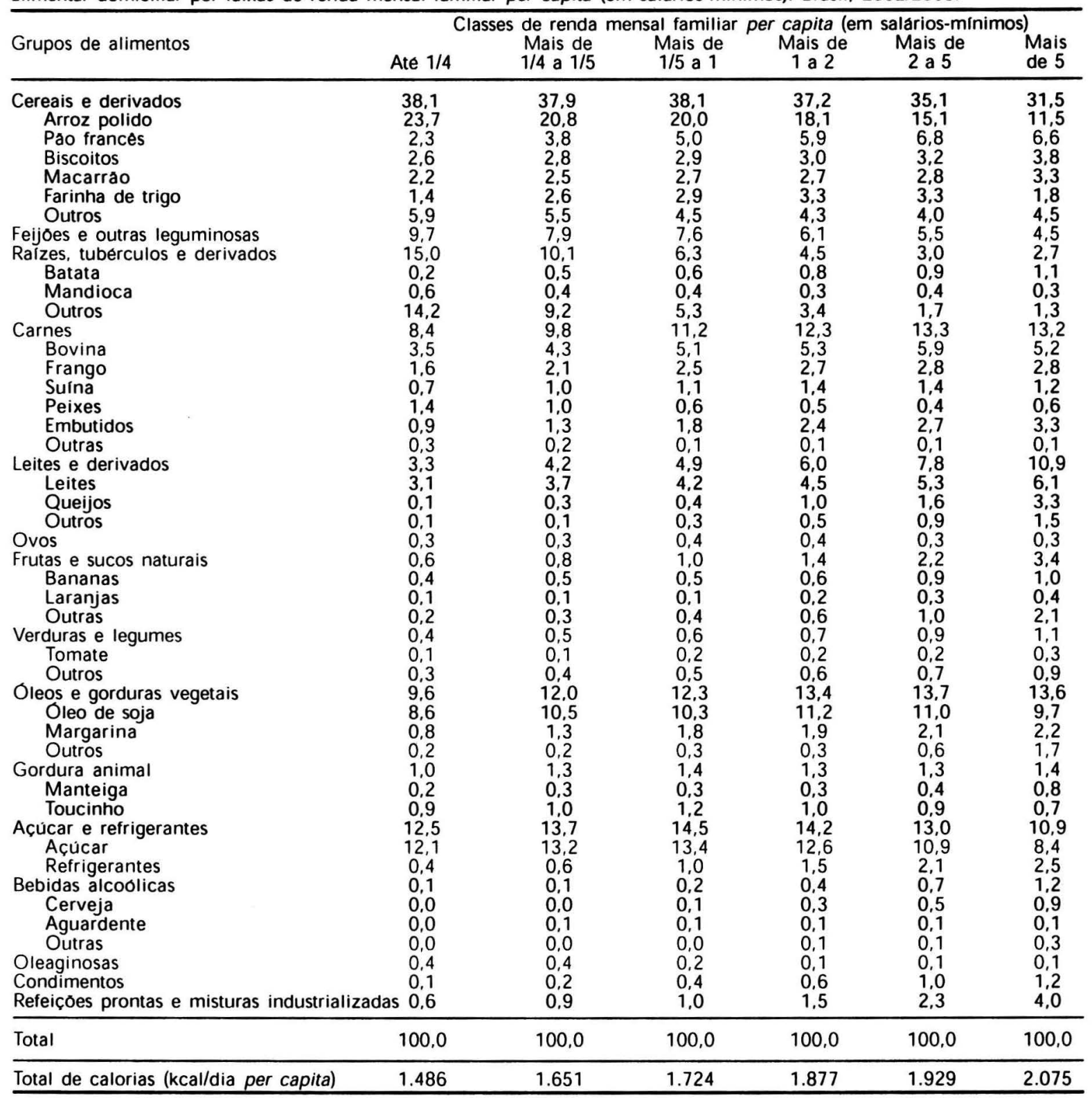


Exemplos de disponibilidade bastante aquém da média nacional são vistos para leite e derivados e verduras e legumes nas regiões Norte e Nordeste e para ovos na região Sudeste.

O efeito do rendimento familiar foi substancial sobre a maioria dos alimentos e grupos de alimentos (Tabela 3). Grupos de alimentos cuja participação na dieta aumentou de forma uniforme com o nível de rendimentos familiares incluem carnes, leite e derivados, frutas, verduras e legumes, bebidas alcoólicas, condimentos e refeições prontas. Grupos de alimentos com tendência inversa incluem feijões e raizes e tubérculos. A participação de cereais e derivados na dieta se mostrou relativamente constante até dois salários-mínimos per capita, declinando a partir de então. Padrões opostos de relação com os rendimentos são vistos para arroz, que apresenta tendência de forte declínio com o aumento da renda, e pão e biscoitos, cujo consumo tende a aumentar com a renda. Padrões também distintos de relação com os rendimentos são observados no grupo açúcar e refrigerantes. No caso do açúcar, há aumento ligeiro com os rendimentos até um salário-mínimo per capita e depois um forte declínio, de modo que o consumo de açúcar na classe de maiores rendimentos foi $50 \%$ in- ferior ao observado na classe de menores rendimentos. No caso dos refrigerantes, houve aumento intenso e contínuo com os rendimentos, de modo que a participação de refrigerantes na dieta foi cinco vezes maior na classe de maiores rendimentos do que na classe de menores rendimentos.

A participação relativa de macronutrientes na disponibilidade alimentar domiciliar indica que 59,6\% das calorias totais provêm de carboidratos, $12,8 \%$ de proteínas e $27,6 \%$ de lipídios. Isso evidencia adequação da dieta às recomendações nutricionais (entre $55 \%$ e $75 \%$ para calorias de carboidratos, entre $10 \%$ e $15 \%$ para calorias protéicas e entre $15 \%$ e $30 \%$ para calorias lipídicas). A proporção de mais de 50\% de proteínas de origem animal (de maior valor biológico) e o teor de ácidos graxos saturados inferior ao limite máximo recomendado de $10 \%$ das calorias totais são igualmente evidências de adequação nutricional da disponibilidade alimentar média nacional. A única evidência de desequilíbrio vem do excesso relativo da fração sacarose dos carboidratos: $13,7 \%$ das calorias totais contra o máximo de $10 \%$ fixado pelas recomendações nutricionais (Tabela 4).

A participação relativa de macronutrientes na die-

Tabela 4 - Participaçáo relativa (\%) de macronutrientes no total de calorias determinado pela aquisiçăo alimentar domiciliar por situaçăo do domicllio, grandes regioes e classes de renda familiar per capita (em salários-minimos). Brasil, $2002 / 2003$.

\begin{tabular}{|c|c|c|c|c|c|c|}
\hline Macronutrientes & Total & \multicolumn{4}{|c|}{$\begin{array}{c}\text { Situaçăo do domicŕlio } \\
\text { Urbano }\end{array}$} & Rural \\
\hline $\begin{array}{l}\text { Carboidratos } \\
\text { Açúcar (sacarose) } \\
\text { Demais carboidratos } \\
\text { Proteinas } \\
\text { Animais } \\
\text { Vegetais } \\
\text { Lipidios } \\
\text { Ácidos graxos mono-insaturados } \\
\text { Ácidos graxos poli-insaturados } \\
\text { Ácidos graxos saturados }\end{array}$ & $\begin{array}{c}59,6 \\
13,7 \\
45,9 \\
12,8 \\
7,0 \\
5,9 \\
27,6 \\
7,3 \\
8,7 \\
8,6 \\
\end{array}$ & \multicolumn{4}{|c|}{$\begin{array}{l}58,1 \\
13,7 \\
44,4 \\
12,9 \\
7,2 \\
5,8 \\
29,0 \\
7,6 \\
9,1 \\
8,9\end{array}$} & $\begin{array}{c}64,6 \\
13,7 \\
50,9 \\
12,4 \\
6,2 \\
6,3 \\
23,0 \\
6,0 \\
7,4 \\
7,7\end{array}$ \\
\hline Macronutrientes & Norte & \multicolumn{3}{|c|}{$\begin{array}{c}\text { Grandes regioes } \\
\text { Sul }\end{array}$} & Sudeste & Centro-Oeste \\
\hline $\begin{array}{l}\text { Carboidratos } \\
\text { Açucar (sacarose) } \\
\text { Demais carboidratos } \\
\text { Proteinas } \\
\text { Animais } \\
\text { Vegetais } \\
\text { Lipidios } \\
\text { Ácidos graxos mono-insaturados } \\
\text { Ácidos graxos poli-Insaturados } \\
\text { Ácidos graxos saturados } \\
\end{array}$ & $\begin{array}{l}62,0 \\
11,1 \\
50,9 \\
13,9 \\
9,1 \\
4,8 \\
24,1 \\
6,2 \\
7,4 \\
8,2\end{array}$ & \multicolumn{3}{|r|}{$\begin{array}{l}55,1 \\
12,5 \\
42,6 \\
14,1 \\
8,3 \\
5,8 \\
30,9 \\
8,5 \\
8,5 \\
9,9\end{array}$} & $\begin{array}{l}57,7 \\
14,5 \\
43,2 \\
12,1 \\
6,4 \\
5,8 \\
30,2 \\
7,9 \\
9,8 \\
9,3 \\
\end{array}$ & $\begin{array}{c}57,8 \\
14,1 \\
43,7 \\
11,9 \\
6,5 \\
5,4 \\
30,4 \\
7,8 \\
11,4 \\
8,6 \\
\end{array}$ \\
\hline Macronutrientes & \multicolumn{2}{|c|}{$\begin{array}{cc}\text { Classes de renda me } \\
\text { Até } 1 / 4 \quad \text { Mais de } \\
1 / 4 \text { a } 1 / 5\end{array}$} & $\begin{array}{l}\text { ISal fami } \\
\text { Mais de } \\
1 / 5 \text { a } 1\end{array}$ & $\begin{array}{c}\text { Ir per capita (er } \\
\text { Mais de } \\
1 \text { a } 2\end{array}$ & $\begin{array}{c}\text { salarios-mínir } \\
\text { Mais de } \\
2 \text { a } 5\end{array}$ & $\begin{array}{l}\text { Mais } \\
\text { de } 5\end{array}$ \\
\hline $\begin{array}{l}\text { Carboidratos } \\
\text { Açúcar (sacarose) } \\
\text { Demais carboidratos } \\
\text { Proteínas } \\
\text { Animais } \\
\text { Vegetais } \\
\text { Lipidios } \\
\text { Ácidos graxos mono-insaturados } \\
\text { Ácidos graxos poli-insaturados } \\
\text { Ácidos graxos saturados }\end{array}$ & $\begin{array}{l}69,2 \\
12,9 \\
56,3 \\
11,7 \\
5,2 \\
6,5 \\
19,1 \\
4,8 \\
6,7 \\
5,9\end{array}$ & $\begin{array}{c}64,6 \\
14,1 \\
50,5 \\
12,0 \\
5,9 \\
6,1 \\
23,5 \\
6,0 \\
8,2 \\
7,2\end{array}$ & $\begin{array}{c}62,2 \\
14,8 \\
47,3 \\
12,5 \\
6,5 \\
6,1 \\
25,3 \\
6,7 \\
8,3 \\
7,8\end{array}$ & $\begin{array}{c}59,2 \\
14,5 \\
44,6 \\
12,8 \\
7,0 \\
5,8 \\
28,1 \\
7,4 \\
9,1 \\
8,7\end{array}$ & $\begin{array}{c}55,8 \\
13,2 \\
42,6 \\
13,4 \\
7,8 \\
5,6 \\
30,8 \\
8,1 \\
9,4 \\
9,7\end{array}$ & $\begin{array}{c}52,2 \\
11,1 \\
41,1 \\
13,9 \\
8,4 \\
5,4 \\
34,0 \\
8,9 \\
9,1 \\
11,2\end{array}$ \\
\hline
\end{tabular}


ta indica semelhanças no que se refere ao teor de proteínas ( $12 \%-14 \%$ das calorias totais), mas diferenças substanciais com relação ao teor de carboidratos e de lipídios (Tabela 4). Isso foi observado segundo a situação do domicílio, as grandes regiões e as classes de renda. Na mesma tabela, note-se que a participação de lipídios na dieta se aproxima ou mesmo supera 30\% (limite superior das recomendações) no meio urbano e de modo geral, nas regiões Sul, Sudeste e Centro-Oeste. O teor de gorduras saturadas está muito próximo do limite máximo de $10 \%$ nas regiões Sul e Sudeste $(9,9 \%$ e $9,3 \%$ das calorias totais). Ainda, o teor de açúcar na dieta supera largamente o limite máximo de $10 \%$ em todo o País.

Aumentos de rendimentos associaram-se a aumento intenso no teor da dieta em gorduras e diminuição igualmente intensa no teor de carboidratos. No caso dos carboidratos, a contribuição mínima de $55 \%$ das calorias totais não se cumpre para a classe de rendimentos mensais superior a cinco salários-mínimos per capita, com o agravante de que cerca de um quinto dos carboidratos da dieta nesta classe de renda $(11 \%$ em $52 \%$ ) correspondem a açúcar. No caso das gorduras, o limite máximo de $30 \%$ das calorias totais é ultrapassado a partir da classe de rendimentos mensais de mais de dois salários-mínimos per capita. Gorduras saturadas tendem a aumentar ainda mais intensamente com a renda do que as demais gorduras. Sua contribuição máxima na dieta, de $10 \%$ das calorias totais, é virtualmente alcançada com os rendimentos mensais per capita entre dois e cinco salários-mínimos $(9,7 \%)$

Tabela 5 - Evolução da participaçâo relativa (\%) de alimentos e grupos de alimentos no total de calorias determinado pela aquisição alimentar domiciliar nas áreas metropolitanas e município de Goiania. Brasil, 1974/1975 - 2002/2003.

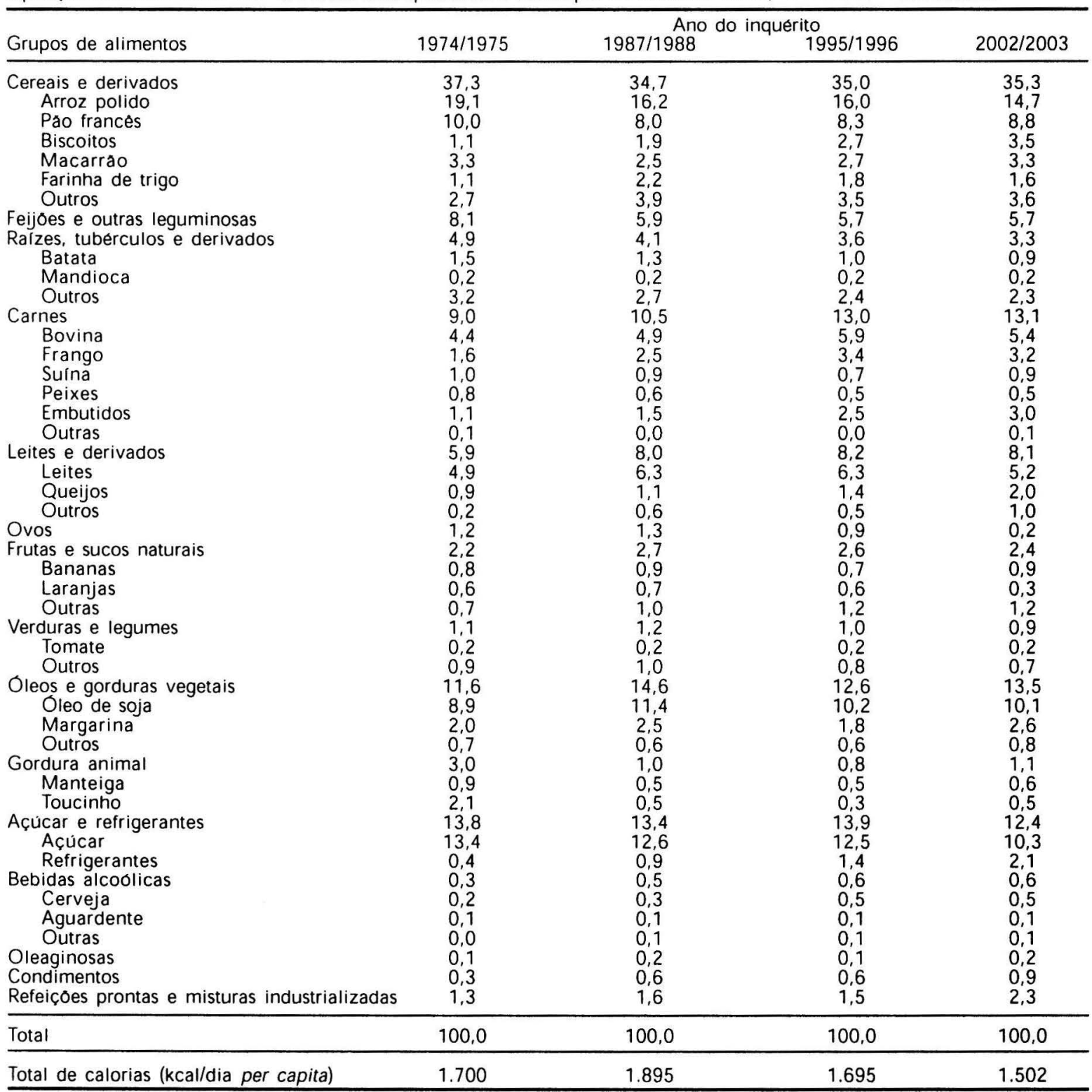


Tabela 6 - Evolução da participaçăo relativa (\%) de macronutrientes no total de calorias determinado pela aquisiçáo alimentar domiciliar nas áreas metropolitanas e município de Goiania. Brasil, 1974/1975 - 2002/2003.

\begin{tabular}{|c|c|c|c|c|}
\hline \multirow[b]{2}{*}{ Macronutrientes } & \multirow[b]{2}{*}{$1974 / 1975$} & \multicolumn{2}{|c|}{ Brasil metropolitano } & \multirow[b]{2}{*}{$2002 / 2003$} \\
\hline & & $1987 / 1988$ & $1995 / 1996$ & \\
\hline $\begin{array}{l}\text { Carboidratos } \\
\text { Acúcar (sacarose) } \\
\text { Demais carboidratos }\end{array}$ & $\begin{array}{l}61,7 \\
14,0 \\
47,6\end{array}$ & $\begin{array}{l}58,0 \\
13,7 \\
44,3\end{array}$ & $\begin{array}{l}57,7 \\
14,2 \\
43,6\end{array}$ & $\begin{array}{l}55,9 \\
12,6 \\
43,3\end{array}$ \\
\hline Proteinas & 12,6 & 12,8 & 13,8 & 13,6 \\
\hline Animais & 6,0 & 7,1 & 8,1 & 7,8 \\
\hline Vegetais & 6,6 & 5,8 & 5,7 & 5,8 \\
\hline Acidos graxos poli-Insaturados & 7,7 & 9,5 & 8,5 & 8,9 \\
\hline Acidos graxos saturados & 7,5 & 8,5 & 8,8 & 9,6 \\
\hline
\end{tabular}

e claramente ultrapassada para famílias com rendimentos de mais de cinco salários-mínimos per capita (11,2\% das calorias totais). O limite máximo de $10 \%$ para a proporção de calorias provenientes de açúcar é ultrapassado em todas as classes de rendimento. A situação mais crítica corresponde às classes intermediárias de rendimentos, onde a participação do açúcar alcança quase $15 \%$ (Tabela 4 ).

Variações importantes em indicadores da disponibilidade domiciliar de alimentos foram observadas nas áreas metropolitanas do País no período 19742003, seja com relação à participação relativa de alimentos e grupos de alimentos, ou aos macronutrientes na dieta. A participação na dieta aumentou para carnes em geral (aumento de quase 50\%), carne bovina $(+22 \%)$, carne de frango $(+100 \%)$, embutidos $(+300 \%)$, leite e derivados $(+36 \%)$, óleos e gorduras vegetais $(+16 \%)$, biscoitos $(+400 \%)$ e refeições prontas $(+80 \%)$. Alimentos e grupos de alimentos que mostraram tendência inversa incluem arroz (redução de $23 \%$ ), feijões e outras leguminosas $(-30 \%)$, raízes e tubérculos $(-30 \%)$, peixes $(-50 \%)$, ovos $(-84 \%)$ e gordura animal ( $-65 \%)$. Açúcar e refrigerantes mostraram tendências opostas no período, com redução do primeiro (23\%) e aumento do segundo $(400 \%)$. A participação de frutas e verduras e legumes na dieta permaneceu relativamente constante durante todo o período (entre $3 \%$ e $4 \%$ ) e bastante aquém, portanto, da recomendação de 6 a $7 \%$ das calorias totais para a ingestão deste grupo de alimentos (Tabela 5).

A evolução da composição da dieta em macronutrientes evidenciou aumento do teor em gorduras e diminuição do teor em carboidratos. No caso dos carboidratos, chega-se muito próximo, no último inquérito, da contribuição mínima de $55 \%$ das calorias totais, com o agravante de que cerca de um quinto dos carboidratos da dieta ( $12 \%$ em $56 \%$ ) correspondem a açúcar. No caso das gorduras, no último inquérito, o limite máximo de $30 \%$ das calorias totais é ultrapassado. Gorduras saturadas tendem a aumentar intensa e continuamente entre os inquéritos, sendo que seu limite máximo na dieta ( $10 \%$ das calorias totais) é virtualmente alcançado no último inquérito $(9,6 \%)$. O limite máximo de $10 \%$ para a proporção de calorias provenientes de açúcar é ultrapassado em todos os inquéritos ainda que tenha havido algum declínio entre os dois últimos. Embora o teor de proteínas na dieta mostre tendência de aumento, a proporção de calorias protéicas se mostrou adequada nos quatro inquéritos (Tabela 6).

\section{DISCUSSÃO}

Devido à excepcional abrangência territorial da $\mathrm{POF}$ realizada em 2002-2003, foi possível descrever, pela primeira vez no Brasil, a situação recente e a distribuição regional e socioeconômica de importantes indicadores do padrão alimentar da população.

Características positivas do padrão alimentar, encontradas em todas as regiões e em todas as classes de rendimento, foram a adequação do teor protéico das dietas e o elevado aporte relativo de proteínas de alto valor biológico (proteínas de origem animal). Características negativas, também amplamente disseminadas no País, foram o excesso de açúcar e a presença insuficiente de frutas e hortaliças na dieta. Nas regiões economicamente mais desenvolvidas (Sudeste, Sul e Centro-Oeste) e, de modo geral, no meio urbano e entre famílias com maior rendimento, além do consumo excessivo de açúcar, houve também consumo excessivo de gorduras em geral e de gorduras saturadas.

A evolução dos padrões de consumo alimentar nas últimas três décadas, passível de estudo apenas nas áreas metropolitanas do Brasil, evidenciou declínio no consumo de alimentos básicos e tradicionais da dieta do brasileiro, como o arroz e o feijão. Houve aumentos de até $400 \%$ no consumo de produtos industrializados, como biscoitos e refrigerantes, persistência do consumo excessivo de açúcar e insuficiente de frutas e hortaliças e aumento sistemático no teor da dieta em gorduras em geral e em gorduras saturadas. Tomados em conjunto, os resultados encontrados apontam para tendências desfavoráveis do padrão alimentar, sobretudo do ponto de vista da obesi- 
Mesmo com limitações, as aquisições familiares dade, diabetes, doenças cardiovasculares, certos tipos de câncer e outras enfermidades crônicas associadas a dietas com alta densidade energética, escassez de fibras e micronutrientes e excesso de gorduras em geral e de gorduras saturadas. ${ }^{23}$ Estudos anteriores sobre disponibilidade domiciliar de alimentos nas áreas metropolitanas indicam que parte dessas tendências têm inicio entre as décadas de 60 e 70 e se intensificam nas décadas de 80 e $90 .^{10,11}$

$\mathrm{Na}$ análise de dados de aquisição de alimentos para consumo domiciliar é necessário considerar inicialmente que esses dados são altamente dependentes do consumo que é feito fora do domicílio. ${ }^{22}$ No municipio do Rio de Janeiro, em 1996, aproximadamente $50 \%$ das refeições de homens adultos, referentes ao almoço e lanche da tarde, eram realizadas fora do domicilio e sem utilizar alimentos provenientes do domicílio. ${ }^{18}$ Embora a POF 2002-2003 tenha investigado pela primeira vez, a despesa associada a cada item da alimentação fora de casa e o tipo de estabelecimento onde as refeições foram realizadas, não foram especificados suficientemente o tipo e a quantidade dos alimentos adquiridos. Essa é, sem dúvida, uma limitação importante das estimativas do presente estudo. Outra limitação, inerente a todas as pesquisas de orçamento familiar, é a não consideração da fração dos alimentos adquiridos que não é consumida pelos moradores do domicílio.

Deve-se, ainda, destacar que o curto período de referência (uma semana) para a coleta de dados sobre a aquisição de alimentos pelas famílias determina que estimativas da POF devam ser calculadas a partir de agregados de famílias e não de famílias individuais. Adicionalmente, a variação nos requerimentos energéticos dos vários estratos da população não foi considerada, o que não permite deduzir, por exemplo, que a probabilidade de déficits calóricos no País seja maior no meio urbano do que no meio rural. Nesse caso, o mais provável, de fato, é que a menor disponibilidade de calorias no meio urbano reflita maior freqüência de consumo alimentar fora do domicílio e, possivelmente, também, necessidades energéticas menores do que no meio rural. Entretanto, dados sobre aquisição de alimentos podem fornecer informações úteis sobre o padrão alimentar das famílias, sobretudo quando os indicadores utilizados focalizem, como no presente estudo, a participação relativa dos diferentes alimentos e grupos de alimentos e não as quantidades absolutas dos mesmos. Note-se, ainda, que as pesquisas de orçamento familiar refletem o inicio da cadeia de consumo, permitindo estabelecer políticas públicas que podem modificar a oferta de alimentos e os padrões de compra da população. guardam relação com o padrão de consumo individual, como apresentado em estudo que modelou com correção para idade, sexo e alterações decorrentes do processamento e perdas, dados de orçamento familiar de consumo alimentar europeu em relação a dados provenientes de consumo individual. ${ }^{13}$ Nesse estudo, as correlações entre aquisição e consumo efetivo do alimento foram maiores do que 0,80 para carnes, leite e derivados, hortaliças e frutas. Em outro estudo, a comparação entre aquisição e consumo efetivo de alimentos mostrou razoável concordância para todos grupos de alimentos, exceto produtos de confeitaria e bebidas alcoólicas.'

Quanto à evolução temporal dos indicadores avaestimativa conservadora das mudanças que ocorreram no padrão da dieta brasileira nas últimas três décadas. Uma vez que apenas as populações vivendo em áreas metropolitanas foram consideradas, não foram captadas todas as mudanças decorrentes da intensa urbanização do País observada no período. De qualquer modo, tendências muito claras e preocupantes foram detectadas com relação a alguns alimentos, destacando-se o aumento de $400 \%$ observado com relação a refrigerantes e biscoitos. $\mathrm{O}$ aumento notável no consumo de refrigerantes preocupa, pois há evidências de que o consumo desses produtos esteja associado ao maior consumo de calorias e ao ganho excessivo de peso em adolescentes. ${ }^{7,9}$ Há evidências, ainda, de que as calorias presentes em alimentos líquidos são menos reconhecidas pelo organismo do que as presentes em alimentos sólidos. ${ }^{21}$ Os biscoitos por sua vez são uma das principais fontes de ácidos graxos trans da dieta, ao lado de margarinas e produtos fritos, principalmente aqueles comercializados em cadeias de fast-food. Ácidos graxos trans assumem configuração parecida com a dos ácidos graxos saturados e são considerados um dos principais fatores da dieta com importante efeito hipercolesterolêmico, elevando a lipoproteína de baixa densidade e reduzindo a lipoproteína de alta densidade. Portanto, seu consumo deve ficar abaixo de $1 \%$ do consumo calórico total. ${ }^{23}$

Finalmente, destaca-se que as tendências de evolução do padrão alimentar da população brasileira reveladas pelo presente estudo são consistentes com a participação crescente de doenças crônicas não transmissíveis no perfil de morbi-mortalidade da população brasileira e, particularmente, com o aumento da prevalência do excesso de peso e da obesidade no País, evidenciado desde os anos $80,{ }^{12,17}$ e mais uma vez confirmado a partir dos dados antropométricos colhidos pela POF 2002-2003. ${ }^{6}$ liados, os dados da pesquisa devem ser tomados como 


\section{REFERENCIAS}

1. Becker W. Comparability of household and individual food consumption data - evidence from Sweden. Public Health Nutr 2001;4:1177-82.

2. Franco G. Tabela de composiçăo química dos alimentos. 9ª ed. São Paulo: Atheneu; 1992.

3. Instituto Brasileiro de Geografia e Estatística (IBGE). Tabela de composiçăo de alimentos. $4^{\mathrm{a}}$ ed. Rio de Janeiro: IBGE. [Estudo Nacional da Despesa Familiar - ENDEF]; 1996

4. Instituto Brasileiro de Geografia e Estatística (IBGE). Pesquisa de Orçamentos Familiares 1987 e 1996. Rio de Janeiro: IBGE; 1999. Disponivel em http:// www.sidra.ibge.gov.br/bda/tabela/ listabl.asp?c $=419 \& z=p 80=8$ [1 out 2004]

5. Instituto Brasileiro de Geografia e Estatistica (IBGE). Pesquisa de orçamentos familiares, 2002-2003. Aquisição alimentar domiciliar per capita, Brasil e grandes regioes. Rio de Janeiro; 2004.

6. Instituto Brasileiro de Geografia e Estatística (IBGE). Pesquisa de Orçamentos Familiares 2002-2003: análise da disponibilidade domiciliar de alimentos e do estado nutricional no Brasil. Rio de Janeiro; 2004.

7. James J, Thomas P, Cavan D, Kerr D. Preventing childhood obesity by reducing consumption of carbonated drinks: cluster randomised controlled trial. BMJ 2004;328:1237.

8. Lagiou P, Trichopoulou A. The DAFNE initiative: the methodology for assessing dietary patterns across Europe using household budget survey data. Public Health Nutr 2001:4:1135-41

9. Ludwig DS, Peterson KE, Gortmaker SL. Relation between consumption of sugar-sweetened drinks and childhood obesity: a prospective, observational analysis. Lancet 2001:357:505-8.

10. Mondini L, Monteiro CA. Mudanças no padrăo de alimentação na populaçáo urbana brasileira (19621988). Rev Saúde Pública 1994:28(6):433-9.

11. Monteiro CA, Mondini L, Levy-Costa RB. Mudanças na composiçáo e adequaçăo nutricional da dieta familiar nas áreas metropolitanas do Brasil (19881996). Rev Saúde Püblica 2000;34(3):251-8.

12. Monteiro CA, Benicio MHD'A, Conde WL, Popkin BM. Shifting obesity trends in Brazil. Eur J Clin Nutrit 2000:54:342-6.
13. Naska A, Paterakis S, Eeckman H, Remaut AM, Trygg K. Methodology for rendering household budget and individual nutrition surveys comparable, at the leve of the dietary information collected. Public Health Nutr 2001:4:1153-8.

14. Núcleo de Estudos e Pesquisas em Alimentaçâo. Universidade Estadual de Campinas [NEPA] Unicamp]. Tabela Brasileira de Composiçăo de Alimentos [TACO]: versão 1. São Paulo: NEPA/ Unicamp: 2004.

15. Nutrition country profiles-Brazil, Rome: FAO; 2000. Disponivel em http://www.fao.org/es/ESN/nutrition/ bra-e.stm [1 nov 2004]

16. Serra-Majem L, MacLean D, Ribas L, Brule D, Sekula W. Prattala $R$ et al. Comparative analysis of nutrition data from national, household, and individual levels: results from a WHO-CINDI collaborative project in Canada, Finland, Poland, and Spain. J Epidemiol Commun Health 2003:57:74-80.

17. Sichieri R, Coitinho DC, Leão $M M$, Recine $E$, Everhart JE. High temporal, geografic, and income variation in body mass index among adults in Brazil. Am J Public Health 1994;84(5):793-8.

18. Sichieri, R. Epidemiologia da obesidade. Rio de Janeiro: UERJ; 1998. p. 140.

19. Souci SW, Fachmann W. Draut $H$. Food composition and nutrition tables, $5^{\text {th }}$ ed. Stuttgart: Medpharm Scientific; 1994.

20. Trichopoulou A. Naska A, and the DAFNE III Group. European food availability databank based on household budget surveys. Eur I Public Health 2003:13(3 Suppl):24-8.

21. Van Wymelbeke V, Beridot-Therond ME, de La Gueronniere V. Fantino M. Influence of repeated consumption of beverages containing sucrose or intense sweeteners on food intake. Eur J Clin Nutr 2004;58:154-61.

22. Vasdekis VGS, Stylianou S, Naska A. Estimation of age and gender-specific food availability from household budget survey data. Public Health Nutr 2001;4:1149-51.

23. World Health Organization. Food and Agriculture Organization [WHO/FAO]. Diet, nutrition and the prevention of chronic diseases. Geneva; 2003. [WHO - Technical Report Series, 916] 
3. ARTIGO 2

Aquisição de açúcar e valor calórico total da disponibilidade domiciliar de alimentos no Brasil. 


\section{Aquisição de açúcar e valor calórico total da disponibilidade domiciliar de alimentos no Brasil.}

\section{Resumo}

Objetivo: Estudar a influência que a aquisição de calorias provenientes de açúcar (açúcar de mesa ou açúcar presente em alimentos processados) exerce sobre o total de calorias adquiridas pelas famílias brasileiras. Metodologia: Utilizaram-se dados sobre aquisição de alimentos coletados pela da Pesquisa de Orçamentos Familiares - POF, realizada entre junho de 2002 e julho de 2003, pelo IBGE, em uma amostra probabilística de 48.470 domicílios do país. As unidades de observação para este estudo correspondem a cada um dos 443 estratos de domicílios da amostra da POF, formados por conjuntos de domicílios pertencentes a setores censitários semelhantes quanto à localização geográfica e nível de escolaridade dos chefes de família. As quantidades de açúcar e de alimentos em geral que cada estrato adquiriu ao longo de 12 meses foram transformadas em calorias utilizando tabelas de composição de alimentos. Modelos de regressão linear múltiplos foram utilizados para estudar a associação entre calorias adquiridas de açúcar e valor calórico total da aquisição de alimentos (VCT), com o controle de variáveis sócio-demográficas. Resultados: 
Evidenciou-se associação positiva e significante entre aquisição de calorias provenientes de açúcar e VCT da aquisição domiciliar de alimentos. Para cada caloria adquirida de açúcar refinado haveria um acréscimo no total calórico de 3,23 calorias. Verificou-se, ainda, que, na condição de ausência de gasto com alimentação fora de casa, a aquisição de açúcar levaria a aquisição total de calorias a valores muito superiores aos recomendados para o consumo da população brasileira. Conclusões: Os resultados deste estudo corroboram as orientações da Organização Mundial de Saúde e do Ministério da Saúde que recomendam a redução no consumo de açúcar. 


\section{Introdução}

As mudanças no estilo de vida decorrentes da industrialização, urbanização e globalização vêm se acelerando em todo mundo, repercutindo também na composição das dietas. Isso tem acarretado um impacto significante no estado de saúde e nutrição da população, particularmente nos países em desenvolvimento ou em transição nutricional (WHO/FAO 2003). As principais mudanças na composição das dietas têm sido o aumento do consumo de gorduras e açúcares e a diminuição na quantidade de carboidratos complexos. A contribuição calórica dos carboidratos na dieta mundial varia de 40 a $80 \%$ e tende a estar inversamente correlacionada ao nível de desenvolvimento dos países. Os açúcares contribuem com 9 a $27 \%$ das calorias totais da dieta, apresentando relação inversa com 0 total de carboidratos (FAO/WHO 1998). Nos EUA, os açúcares adicionados aos alimentos e preparações contribuem com $15,8 \%$ do total calórico da dieta, sendo os refrigerantes responsáveis por um terço do consumo total de açúcares de adição. Neste país, a média de consumo de açúcares de adição varia de 10 a 30 colheres de sopa por dia, o que corresponde de 40 a $120 \mathrm{~g} /$ dia por adulto (IOM 2002). 
Recente estudo de revisão sobre a disponibilidade de alimentos no mundo verificou um aumento de $75 \mathrm{kcal}$ diárias per capita provenientes do consumo de açúcar (um aumento de $32 \%$ ) no período entre 1962 e 2000. A urbanização e o aumento da renda nos países teriam sido responsáveis por $82 \%$ do aumento no consumo de açúcar, sendo o restante atribuído a fatores relacionados à mudança de comportamento do consumidor e/ou da indústria de alimentos (POPKIN and NIELSEN 2003).

Nos Estados Unidos, o consumo de açúcar per capita entre indivíduos com mais de dois anos de idade cresceu em $83 \mathrm{kcal} / \mathrm{dia}$ no período de 1977 a 2000, o que elevou em 22\% a participação do açúcar no valor calórico total da dieta (de 13\% para 15,8\%). No aumento de $83 \mathrm{kcal}, 54 \mathrm{kcal}$ corresponderam ao consumo de refrigerante e $13 \mathrm{kcal}$ ao de sucos de frutas adoçados. Especificamente entre adolescentes, observou-se um aumento do consumo de refrigerantes em detrimento do consumo de leite (POPKIN and NIELSEN 2003).

Na América Latina, estudo mostra tendência de aumento da disponibilidade de açúcar, além de um declínio do consumo de cereais, frutas e hortaliças (BERMUDEZ and TUCKER 2003). 
No Brasil, a evolução do padrão alimentar das famílias residentes em áreas metropolitanas, estabelecida a partir de Pesquisas de Orçamentos Familiares (POF) realizadas entre 1987 e 1996, indica ligeiro aumento de uma alta participação de açúcar na dieta (de $13,5 \%$ para $13,9 \%$ das calorias totais disponíveis para consumo) (MONTEIRO et al 2000).

Em 2002-2003 a realização de uma POF de abrangência nacional permitiu descrição do padrão de consumo familiar de todas as regiões do país e uma atualização da evolução do padrão alimentar nas áreas metropolitanas, para as quais se dispunha de dados para períodos anteriores. Os resultados evidenciaram uma participação excessiva de açúcar na dieta (mais do que $10 \%$ do total de calorias disponíveis para o consumo) em todas as regiões do país e em todas as classes de renda. Com relação à tendência de evolução dos padrões de consumo alimentar nas áreas metropolitanas brasileiras, evidenciou-se persistência de um teor excessivo de açúcar nas dietas, com redução da fração correspondente ao açúcar de mesa e aumento da fração correspondente ao açúcar dos alimentos processados, em particular do açúcar em refrigerantes (LEVY-COSTA et al 2005). 
Os possíveis efeitos prejudiciais à saúde decorrentes do consumo de açúcar na dieta, especialmente quando consumido em grande quantidade, vêm sendo discutido mundialmente (WHO/FAO 2003, FAO/WHO 1998 e IOM 2002).

O consumo do açúcar, além de fornecer energia, promove uma sensação de prazer devido às suas propriedades organolépticas (ANDERSON 1995). Fisiologicamente, após a sua ingestão, ocorre uma rápida elevação na concentração da glicose sanguínea. $\mathrm{O}$ organismo responde a esse aumento com a liberação de insulina em quantidades elevadas, acarretando a redução da concentração de glicose a valores inferiores ao normal. Tal mecanismo provoca sensação de fome e pode induzir ao consumo excessivo de calorias (ANDERSON and WOODEND 2003). 0 efeito do açúcar no consumo calórico total pode, portanto, dever-se aos dois fatores, hedônico e fisiológico (ANDERSON 1995).

Estudos experimentais em seres humanos indicam que 0 consumo energético aumenta com a densidade energética da dieta e que o açúcar e as gorduras contribuem para o aumento dessa densidade (STUBBS et al 2000, ROLLS and BELL 2000). Outros estudos sugerem que 0 consumo de bebidas açucaradas eleva 0 valor calórico total da dieta limitando o mecanismo de controle do 
apetite e provocando uma redução do efeito compensatório do consumo alimentar (DIMEGLIO and MATTES 2000, LUDWIG 2002, VAN WYMELBEKE 2004).

O efeito do consumo excessivo de açúcar sobre a qualidade da dieta, tanto no que diz respeito à diluição de micronutrientes quanto à diminuição da ingestão de alimentos saudáveis, tem sido evidenciado em diversos estudos (POPKIN and NIELSEN 2003, KRANZ et al 2005, RAJESHWARI et al 2005). A associação entre o consumo excessivo de refrigerantes e maior consumo de calorias também foi evidenciada em vários estudos (DREWNOWSKI and BELLISLE 2007, EBBELING et al 2006). No presente estudo, pretende-se estudar a influência que a aquisição de calorias provenientes do açúcar de mesa ou do açúcar presente em alimentos processados exerce sobre o total de calorias adquiridas pelas famílias brasileiras, utilizando para isso os dados da Pesquisa de Orçamentos Familiares do IBGE de 2002-2003. 


\section{Métodos}

Todos os dados utilizados neste estudo são originários da Pesquisa de Orçamentos Familiares realizada pelo Instituto Brasileiro de Geografia e Estatística no período de junho de 2002 a julho de 2003 (POF 2002-2003).

\section{Amostragem}

O desenho da amostra da POF 2002-2003 foi estruturado de modo a representar o conjunto dos domicílios brasileiros, bem como as cinco grandes regiões do país conforme situação urbana ou rural, os 26 estados brasileiros, as nove regiões metropolitanas e as capitais dos 26 estados no que se refere à situação urbana. Trata-se de uma amostra estratificada, sorteada em dois estágios. Os estratos, em número de 443 , foram formados agrupando-se os setores censitários do país com base em critérios geográficos (estado, região e situação urbana ou rural do setor) e socioeconômicos (média de escolaridade do chefe do domicílio no setor, segundo o Censo Demográfico de 2000). O sorteio de setores censitários (unidade primária de amostragem) dentro de cada estrato foi feito por amostragem sistemática com probabilidade proporcional ao número de domicílios no setor. $\mathrm{O}$ 
sorteio de domicílios (unidade secundária de amostragem) dentro de cada setor foi feito por amostragem aleatória simples, sem reposição. Para que a coleta de dados fosse uniforme nos quatro trimestres do ano, as entrevistas realizadas dentro de cada um dos 443 estratos foram distribuídas para estudo ao longo dos doze meses de duração da pesquisa. No período, foram entrevistados 48.470 domicílios distribuídos em 3.984 setores.

O período de referência utilizado pela POF 2002-2003 para a coleta de informações sobre aquisição de alimentos em cada domicílio é de apenas sete dias, 0 que não permite uma caracterização adequada do padrão de aquisição de alimentos no domicílio. Por esta razão, na presente investigação, optou-se por adotar como unidade de estudo, não o domicílio individual estudado pela pesquisa, mas o conjunto de domicílios existentes em cada um dos 443 estratos da amostra. O número médio de domicílios estudado dentro de cada um dos 443 estratos da POF 2002-2003 foi de 109,6, variando de 9 a 804 domicílios. O fator amostral de ponderação de cada estrato resultou da somatória dos fatores amostrais de ponderação dos domicílios pertencentes a cada estrato. 


\section{Coleta de dados}

As informações referentes aos alimentos adquiridos em cada domicílio foram obtidas utilizando a caderneta de despesa coletiva da pesquisa. Nesta caderneta foram registradas todas as aquisições de alimentos feitas durante um período de sete dias consecutivos incluindo quantidade, unidade de medida com seu equivalente em peso ou volume, valor da despesa, local de compra e a forma de obtenção do alimento. Em cerca de $75 \%$ dos domicílios, os dados sobre aquisição de alimentos foram registrados em meio eletrônico, no próprio momento da coleta de dados, com a utilização de computadores portáteis, o que possibilitou a verificação da consistência das informações e a correção de erros ainda no domicílio.

\section{Construção de variáveis}

As variáveis centrais deste estudo são o total de calorias adquiridas pelos domicílios que constituem cada estrato da pesquisa e o total de calorias provenientes de açúcar. Neste último caso, foram considerados tanto o açúcar de mesa quanto os açúcares adicionados pela indústria aos alimentos processados. Rapadura, melado, mel e outros adoçantes calóricos, embora 
representem proporção diminuta do total de calorias adquiridas pelas famílias brasileiras, foram igualmente consideradas no cômputo do total de calorias provenientes de açúcar. Os açúcares intrínsecos, presentes naturalmente nos alimentos, como a frutose nas frutas e a lactose nos leites, foram considerados como parte do restante da alimentação, que não inclui o açúcar. Os procedimentos empregados para se obter essas variáveis foram os seguintes: 1) soma das quantidades adquiridas de um mesmo alimento (em gramas) ao longo dos sete dias de coleta; 2) aplicação para cada alimento de fator de correção que leva em conta apenas a parte comestível do alimento (IBGE 1996); 3) conversão da quantidade adquirida de cada alimento em calorias totais e calorias provenientes de açúcar, empregando-se para tanto a tabela TACO (Tabela Brasileira de Composição de Alimentos) (NEPA 2004) ou a tabela oficial de composição nutricional americana, versão 15 (USDA 2004), quando o alimento não estava disponível na primeira tabela. No caso específico da conversão para as calorias provenientes de açúcar, o cálculo envolveu duas etapas: a conversão de quantidades (em gramas) para calorias provenientes de carboidratos (usando, sempre que possível a tabela TACO) e a conversão das calorias provenientes de carboidratos para calorias provenientes de açúcar (usando a tabela americana, uma vez que a tabela brasileira não detalha os tipos de 
carboidratos); 4) somatória das calorias totais e das calorias de açúcar adquiridas pelos domicílios de um mesmo estrato e divisão pela somatória do número de indivíduos no estrato (fatores amostrais de ponderação de cada domicílio foram utilizados nesta etapa).

Atributos sócio-demográficos dos estratos foram utilizados para caracterizar as unidades de estudo e para controlar possíveis efeitos de confusão sobre a associação entre calorias adquiridas de açúcar e valor calórico total de aquisição domiciliar de alimentos. Tais variáveis incluíram: a macro região onde se situava o estrato (Norte, Nordeste, Sudeste, Sul e Centro Oeste) e sua inserção em área urbana ou rural, além dos valores médios no estrato da renda domiciliar per capita, da proporção do gasto total com alimentos realizado fora do domicílio, e do percentual de menores de 20 anos, de maiores de 64 anos e de mulheres. Para se chegar aos valores médios no estrato, foram empregados os fatores amostrais de ponderação de cada domicílio pertencente ao estrato.

\section{Análise dos dados}

A associação bruta entre aquisição de calorias de açúcar e valor calórico total (VCT) da aquisição domiciliar de alimentos foi 
descrita calculando-se a média do VCT em agrupamentos dos estratos de domicílios definidos a partir da distribuição em quartis da aquisição de calorias provenientes do açúcar.

A associação entre aquisição de calorias de açúcar e valor calórico total, ajustada para variáveis de confusão, foi estudada por meio de modelo de regressão linear múltiplo tendo o VCT da aquisição domiciliar de alimentos como variável dependente. Foram introduzidos nos modelos, além das calorias adquiridas de açúcar (variável explanatória), todas as variáveis que apresentaram valor p inferior a 0,20 em modelos de regressão linear bivariados para a associação com o VCT ou com o total de calorias de açúcar (potenciais variáveis de confusão). Utilizou-se a técnica de modelagem "backward", retirando-se do "modelo saturado", uma a uma, as potenciais variáveis de confusão, iniciando-se pela variável com o maior valor $p$. As variáveis que alteraram em pelo menos $5 \%$ a magnitude do coeficiente de regressão das calorias do açúcar sobre o VCT permaneceram no modelo final. Adicionalmente, avaliou-se o possível efeito de interações sobre o VCT da aquisição domiciliar de alimentos, mantendo-se no modelo final todas as interações significativas ( $p$ valor $<0,05)$. Para permitir uma apreciação visual do efeito das interações sobre o VCT da aquisição 
domiciliar de alimentos foram construídos gráficos correspondentes a vários cenários quanto às variáveis presentes nas interações.

A adequação dos modelos finais de regressão foi realizada empregando-se análise de resíduos. Em todas as análises deste estudo, foram utilizados fatores amostrais de ponderação que permitem a extrapolação dos resultados para a população brasileira. Todas as análises foram feitas com o emprego do aplicativo estatístico Stata/SE versão 8.0 (STATA 2003). 


\section{Resultados}

A Tabela 1 mostra que a média de calorias adquirida por cada estrato aumenta de modo uniforme e significativo com o aumento da quantidade adquirida de calorias de açúcar, indicando uma diferença de mais de $800 \mathrm{kcal} /$ per capita/dia entre o primeiro e o quarto quartil da aquisição de calorias de açúcar. Nota-se que o aumento no total de calorias adquiridas é superior ao que seria esperado com base apenas no aumento na aquisição de açúcar.

Tabela 1 - Valor calórico total (VCT) da aquisição domiciliar de alimentos segundo a aquisição de calorias de açúcar em domicílios brasileiros (2002-2003).

\begin{tabular}{l|cc}
\hline \multicolumn{1}{c|}{$\begin{array}{c}\text { Quartis da aquisição de açúcar } \\
\text { (kcal/per capita/dia) }\end{array}$} & \multicolumn{2}{c}{ VCT (kcal/per capita/dia) } \\
Média & ep & p \\
\hline $1^{\circ}(9,2-231,3)$ & & $0,000^{*}$ \\
$2^{\circ}(231,3-290,7)$ & 1416,3 & 38,5 \\
$3^{\circ}(292,0-334,8)$ & 1689,4 & 29,5 \\
$4^{\circ}(334,8-768,2)$ & 1862,8 & 38,0 \\
\hline Total $(\mathbf{9 , 2}-\mathbf{7 6 8 , 2 )}$ & 2261,1 & 92,6 \\
\hline ep erro padrão & $\mathbf{1 8 0 5 , 2}$ \\
*p para tendência linear & \multicolumn{2}{|}{$\mathbf{3 3 , 6}$} \\
\hline
\end{tabular}

A Tabela 2 descreve a relação que variáveis sóciodemográficas mantêm com a aquisição total de calorias e, também, com as calorias provenientes especificamente do açúcar. Associações significantes com o total de calorias adquiridas são observadas no caso da situação urbana ou rural do estrato (maior 
aquisição para situação rural), renda domiciliar (menor aquisição para os dois quartis superiores de renda), percentual do gasto com alimentos fora de casa (aquisição decrescente com o gasto), proporção de idosos nos domicílios (aquisição crescente com a proporção de maiores de 64 anos) e proporção de mulheres nos domicílios (aquisição decrescente com a maior proporção do sexo feminino). Conforme já mencionado, essas variáveis foram introduzidas, em bloco, em um modelo de regressão múltipla das calorias adquiridas de açúcar sobre a aquisição total de calorias. 
Tabela 2 - Médias do valor calórico total da aquisição de alimentos (VCT) e das calorias provenientes de açúcar segundo variáveis sócio-demográficas em domicílios brasileiros (2002-2003).

\begin{tabular}{|c|c|c|c|c|}
\hline Variáveis & $\begin{array}{c}\text { VCT } \\
\text { (kcal/per } \\
\text { capita/dia) }\end{array}$ & $p$ & $\begin{array}{c}\text { Calorias de Açúcar } \\
\text { (kcal/per } \\
\text { capita/dia) }\end{array}$ & $\mathbf{p}$ \\
\hline Região & & 0,486 & & 0,003 \\
\hline Norte & 1882,8 & & 226,4 & \\
\hline Nordeste & 1757,3 & & 276,2 & \\
\hline Sudeste & 1775,6 & & 308,3 & \\
\hline Sul & 1973,6 & & 306,3 & \\
\hline Centro-Oeste & 1714,9 & & 273,1 & \\
\hline Área & & 0,000 & & 0,000 \\
\hline Urbana & 1702,6 & & 278,4 & \\
\hline Rural & 2375,5 & & 368,0 & \\
\hline Renda domiciliar per capita & & $0,014 *$ & & $0,306^{*}$ \\
\hline $1^{\circ}$ quartil & 1803,3 & & 278,5 & \\
\hline $2^{\circ}$ quartil & 1979,3 & & 327,7 & \\
\hline $3^{\circ}$ quartil & 1732,5 & & 286,5 & \\
\hline $4^{\circ}$ quartil & 1705,5 & & 275,3 & \\
\hline $\begin{array}{l}\text { \% de gasto com alimentação fora do } \\
\text { domicílio }\end{array}$ & & $0,000 *$ & & $0,000 *$ \\
\hline $1^{\circ}$ quartil & 2117,2 & & 321,5 & \\
\hline $2^{\circ}$ quartil & 1801,5 & & 302,7 & \\
\hline $3^{\circ}$ quartil & 1702,3 & & 291,3 & \\
\hline $4^{\circ}$ quartil & 1598,5 & & 252,6 & \\
\hline$\%$ de Menores de 20 anos & & $0,486^{*}$ & & $0,066^{*}$ \\
\hline $1^{\circ}$ quartil & 1865,9 & & 298,8 & \\
\hline $2^{\circ}$ quartil & 1783,5 & & 303,5 & \\
\hline $3^{\circ}$ quartil & 1763,2 & & 299,8 & \\
\hline $4^{\circ}$ quartil & 1807,8 & & 265,8 & \\
\hline$\%$ de Maiores de 64 anos & & $0,000 *$ & & $0,000^{*}$ \\
\hline $1^{\circ}$ quartil & 1574,9 & & 235,1 & \\
\hline $2^{\circ}$ quartil & 1792,4 & & 293,8 & \\
\hline $3^{\circ}$ quartil & 1913,8 & & 326,8 & \\
\hline $4^{\circ}$ quartil & 1942,8 & & 313,1 & \\
\hline$\%$ de Mulheres & & $0,000 *$ & & $0,006 *$ \\
\hline $1^{\circ}$ quartil & 2061,1 & & 320,8 & \\
\hline $2^{\circ}$ quartil & 1741,7 & & 284,2 & \\
\hline $3^{\circ}$ quartil & 1750,4 & & 300,5 & \\
\hline $4^{\circ}$ quartil & 1662,9 & & 262,6 & \\
\hline Total & 1805,2 & & 292,0 & \\
\hline
\end{tabular}


Tabela 3 - Resultados do modelo final de regressão linear múltipla (sem interações) relativo à associação entre calorias adquiridas de açúcar e o valor calórico total da aquisição domiciliar de alimentos (kcal/per capita) em domicílios brasileiros (2002-2003).

\begin{tabular}{|c|c|c|c|c|}
\hline Variáveis no Modelo & $\begin{array}{l}\text { Coeficiente } \\
\text { de regressão }\end{array}$ & $\begin{array}{r}\text { Inter } \\
\text { confianç }\end{array}$ & $\begin{array}{l}\text { lo de } \\
\text { de } 95 \%\end{array}$ & $\mathbf{R}^{2}$ \\
\hline $\begin{array}{l}\text { Calorias adquiridas de açúcar (kcal/per capita) } \\
\text { Renda domiciliar (log de } \mathrm{R} \$ / \text { per capita) } \\
\% \text { do gasto em alimentação fora do domicílio } \\
\text { Área }(0=\text { urbano } 1=\text { rural) }\end{array}$ & $\begin{array}{l}3,229 \\
157,507 \\
-12,785 \\
384,589 \\
\end{array}$ & $\begin{array}{r}2,645 \\
87,784 \\
-19,128 \\
251,951 \\
\end{array}$ & $\begin{array}{c}3,814 \\
227,229 \\
-6,442 \\
517,226 \\
\end{array}$ & 0,713 \\
\hline
\end{tabular}

A Tabela 3 apresenta resultados do modelo final de regressão múltipla das calorias de açúcar sobre o total de calorias, incluindo as variáveis de controle cuja retirada modificou em mais de $5 \%$ o coeficiente de regressão associado às calorias de açúcar. Nota-se, inicialmente, que este modelo final, que inclui, além das calorias de açúcar, a renda domiciliar per capita, o percentual do gasto com alimentação fora de casa e a situação urbana ou rural dos domicílios, "explica" mais de dois terços da variabilidade do VCT da aquisição domiciliar de alimentos $\left(r^{2}=0,713\right)$. Na construção do modelo, foram testadas diversas transformações para a variável renda domiciliar, sendo o melhor ajuste obtido por meio da transformação logarítmica.

Nota-se, ainda, que o coeficiente de regressão para as calorias de açúcar $\left(3,229 ;\right.$ IC $^{95 \%} 2,645$ - 3,814) implica que cada caloria adicional de açúcar determina um aumento de mais de três 
calorias no total calórico adquirido pelos domicílios. Ou seja, a aquisição de uma caloria adicional de açúcar leva à aquisição "a mais" de 2,229 calorias provenientes de outros macronutrientes que não o açúcar (gorduras, proteínas ou outros carboidratos). Coeficiente de regressão para as calorias de açúcar de valor igual a 2,229 foi encontrado para modelo de regressão idêntico ao apresentado na Tabela 3, tendo como variável dependente o VCT subtraído das calorias de açúcar (dados não mostrados).

Análises adicionais, feitas a partir do modelo final de regressão múltipla sobre a aquisição total de calorias, revelaram efeitos significativos de interações, duas a duas, entre calorias de açúcar, renda domiciliar e percentual de gasto com alimentação fora do domicílio. A tabela 4 apresenta resultados do modelo final de regressão que contempla o efeito dessas interações sobre a aquisição total de calorias $\left(r^{2}=0,754\right)$. 


\section{Tabela 4 - Resultados do modelo final de regressão linear múltipla (com interação) relativo à associação entre calorias adquiridas de açúcar e o valor calórico total de aquisição domiciliar de alimentos (kcal/per capita) em domicílios brasileiros (2002-2003).}

\begin{tabular}{|c|c|c|c|c|}
\hline Variáveis no modelo & $\begin{array}{l}\text { Coeficiente } \\
\text { de regressão }\end{array}$ & \multicolumn{2}{|c|}{ IC $^{95 \%}$} & $\mathbf{R}^{2}$ \\
\hline Calorias adquiridas de açúcar (kcal/per capita/dia) & $-4,509$ & $-7,982$ & $-1,037$ & \\
\hline Renda domiciliar (log de $\mathrm{R} \$ /$ per capita) & $-501,487$ & $-771,166$ & $-285,790$ & \\
\hline Área $(0=$ urbano $1=$ rural $)$ & 273,240 & 149,443 & 397,037 & \\
\hline \% de gasto em alimentação fora do domicílio & $-22,587$ & $-50,357$ & 5,183 & \\
\hline Calorias de Açúcar * Renda domiciliar & 1,775 & 1,162 & 2,389 & \\
\hline $\begin{array}{l}\text { Calorias de Açúcar * \% de gasto em alimentação fora } \\
\text { do domicílio }\end{array}$ & $-0,142$ & $-0,191$ & $-0,092$ & \\
\hline $\begin{array}{l}\text { Renda domiciliar * \% de gasto em alimentação fora } \\
\text { do domicílio }\end{array}$ & 7,079 & 3,497 & 10,661 & \\
\hline
\end{tabular}

Os sinais, respectivamente, positivo e negativo dos termos de interação entre calorias de açúcar e renda e calorias de açúcar e percentual do gasto em alimentação fora de casa indicam que o efeito positivo da aquisição de açúcar sobre a aquisição total de calorias cresce com o aumento da renda e diminui com o aumento do gasto fora de casa. O sinal negativo do termo isolado "calorias de açúcar" no modelo com interação indica que a quantidade total de calorias adquirida pelas famílias diminui com o aumento de calorias provenientes do açúcar na condição de ausência simultânea de renda e de gastos com alimentação fora de casa. Em todas as outras condições, para se conhecer o efeito do açúcar sobre as calorias totais, é necessário se levar em conta o nível de renda familiar e o percentual do gasto com alimentação fora de casa. Para facilitar a visualização desse efeito, apresentam-se três 
gráficos que consideram diferentes "cenários" para a renda domiciliar e para o percentual do gasto com alimento fora de casa. Nesses gráficos, permite-se observar a variação da quantidade de calorias adquiridas de açúcar entre um mínimo correspondente ao percentil 10 da distribuição da aquisição de açúcar na amostra total da POF 2002-2003 e um valor máximo correspondente ao percentil 90. A renda é fixada em cada um dos três gráficos em valores equivalentes à média da renda observada, respectivamente, no quintil inferior da renda, no quintil intermediário e no quintil superior. Em cada um dos três gráficos, apresenta-se a relação entre calorias de açúcar e calorias totais sem fixar o valor do percentual do gasto com alimentação fora de casa e, também, na condição de percentual zero desse gasto.

Nota-se que nos três cenários estabelecidos para a renda domiciliar, aumentos na aquisição de açúcar determinam aumentos nas calorias totais da aquisição domiciliar de alimentos, sendo sempre maiores os aumentos no cenário de percentual zero de gastos com alimentação fora de casa. São particularmente relevantes as predições para as calorias totais quando é zero o percentual de gasto com alimentação fora de casa, pois, nesta condição, a aquisição domiciliar de alimentos tenderia a se aproximar do consumo real de calorias dos indivíduos. Na condição 
de gasto zero com alimentação fora de casa, uma aquisição relativamente elevada de açúcar (413,6 kcal/per capita/dia ou percentil 90 da distribuição da aquisição de açúcar na amostra da POF) levaria a aquisição total de alimentos para $2770 \mathrm{kcal} / p e r$ capita/dia em domićlios com baixa renda (quintil inferior de distribuição de renda), $2980 \mathrm{kcal} / p e r$ capita/dia em domicílios com renda intermediária (quintil intermediário da distribuição de renda) e $3240 \mathrm{kcal} /$ per capita/dia em domicílios com alta renda (quintil superior da distribuição de renda).

Modelos independentes para domicílios urbanos e rurais foram testados, mas não são apresentados em face de que evidenciaram resultados semelhantes dos dados para o total dos domicílios (dados não mostrados). 
Figura 1 - Estimativas de modelo de regressão linear múltiplo (com interação) para a relação entre aquisição de calorias de açúcar e valor calórico total (VCT) da aquisição domiciliar de alimentos no primeiro quintil, quintil intermediário e quinto quintil da distribuição da renda domiciliar per capita conforme dois cenários para o percentual do gasto em alimentação fora de casa. Brasil, 2002/2003.

10 Quintil

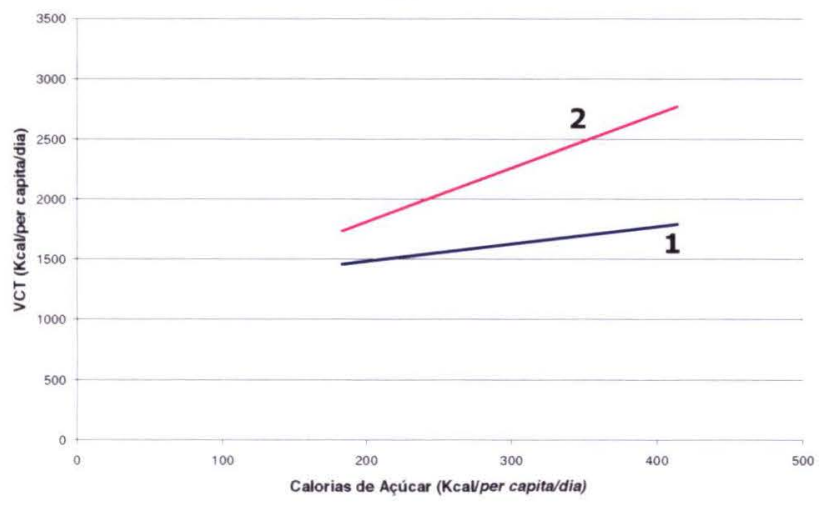

Quintil Intermediário

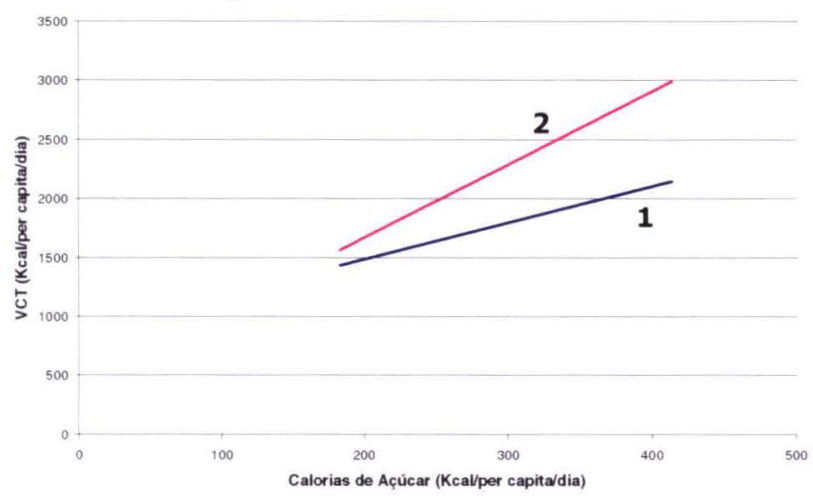

$5^{\circ}$ Quintil

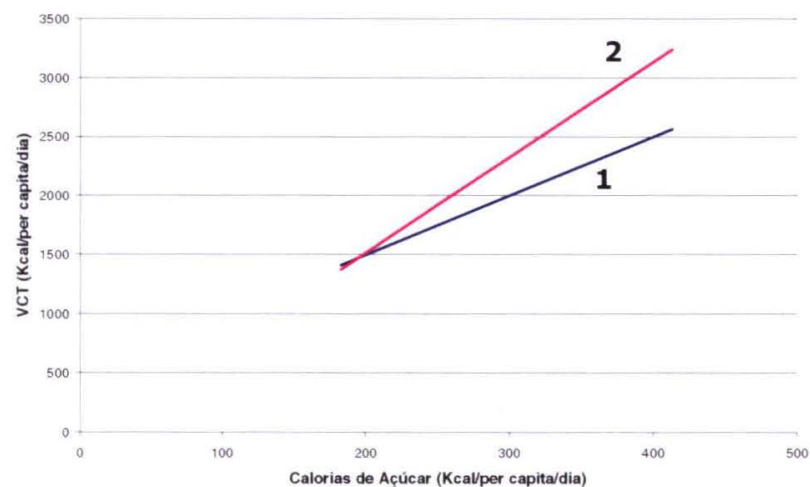

Nota

Cenário 1: Predição feita com a renda domiciliar per capita fixada no valor equivalente à média de renda observada no primeiro quintil, quintil intermediário e quinto quintil da distribuição de renda domiciliar per capita com as demais variáveis explanatórias do modelo, exceto calorias do açúcar, fixada na média observada na amostra de estratos da POF.

Cenário 2: Predição conforme 1 mais a fixação em zero do percentual de gasto em alimentação fora de casa. 


\section{Discussão}

Com base em pesquisa nacional de orçamentos familiares representativa do conjunto dos domicílios brasileiros, o presente estudo evidenciou associação positiva e significativa entre aquisição de calorias provenientes de açúcar e o valor calórico total da aquisição domiciliar de alimentos. Verificou-se, também, que na condição de ausência de despesas com alimentação fora de casa, e, portanto, em um cenário em que a aquisição domiciliar de alimentos tenderia a se aproximar do consumo real dos indivíduos, a aquisição de açúcar levaria a aquisição total de calorias a valores claramente excessivos diante da ingestão de $2000 \mathrm{kcal} / \mathrm{dia}$ recomendadas para a população brasileira (MS 2006).

As principais limitações deste estudo decorrem das limitações das pesquisas de orçamentos familiares para descrever o consumo alimentar das famílias, ou seja, a não consideração dos alimentos consumidos fora de casa e a proporção de alimentos adquiridos mas não consumidos. A essas duas limitações, junta-se, no caso da POF 2002-2003, o curto período (uma semana) de referência para a avaliação das aquisições de alimentos. 
No presente estudo, procurou-se controlar o possível efeito do consumo fora de casa sobre a relação entre calorias adquiridas de açúcar e aquisição total de alimentos utilizando-se nos modelos de regressão múltipla o percentual do gasto com alimentação fora do domicílio. Na presença do controle da renda, parece razoável admitir-se que esse percentual, seja uma "proxy" para o consumo calórico fora do domicílio.

Com relação aos alimentos adquiridos, mas não consumidos, é razoável supor, inicialmente, que isso ocorra com magnitude relevante apenas nos estratos de mais alta renda. Ainda assim, para que a relação indicada pelo presente estudo entre consumo de açúcar e consumo total de calorias fosse afetada pelo eventual "desperdício" de alimentos seria preciso que a proporção não consumida de açúcar fosse diferente da proporção não consumida dos demais alimentos.

Para resolver o problema do curto período de avaliação de cada domicilio na POF, optou-se por eleger como unidades de estudo grupos de domicílios homogêneos quanto a atributos sócioeconômicos e geográficos, garantindo-se, ademais, a caracterização da aquisição de alimentos em cada unidade de estudo ao longo dos quatro trimestres do ano. 
Fala a favor da relativa acurácia da POF na aferição da participação do açúcar na dieta dos brasileiros a proporção de $16,2 \%$ das calorias totais, próxima dos $18,3 \%$ e $18,6 \%$ estimados pela FAO (Organização das Nações Unidas para Agricultura e Alimentação) a partir das folhas de balanço de alimentos do país nos anos de 2002 e 2003, respectivamente (MONTEIRO et al 2006).

Apesar das limitações características das pesquisas de orçamentos familiares, estudos que comparam seus resultados com os obtidos em inquéritos individuais de consumo concluem que existe uma considerável concordância entre os métodos (NASKA et al 2001, BECKER 2001). Por exemplo, em estudo realizado em quatro países europeus, encontrou-se coeficiente de correlação de 0,74 entre consumo de açúcar mensurado por pesquisa de orçamentos familiares e por inquérito individual de consumo (NASKA et al 2001). Há mesmo autores que defendem que, no caso de alimentos utilizados como ingredientes de preparações, como o açúcar, as pesquisas de orçamentos familiares podem refletir melhor o consumo real dos indivíduos, do que os inquéritos individuais de consumo. Isso ocorreria em face da dificuldade dos indivíduos em relatar a quantidade consumida de um alimento que é ingerido como parte de uma preparação (BECKER 2001). 
Dois pontos fortes do presente estudo são a representatividade nacional da amostra de domicílios estudada e o controle estatístico de diversos atributos sócio-demográficos que poderiam atuar como fator de confusão para a associação entre calorias de açúcar e valor calórico total da aquisição domiciliar de alimentos. Ainda assim, com relação a este último aspecto, como em qualquer estudo observacional, não se pode descartar a possibilidade de existência de fatores de confusão não considerados em nossa análise.

Estudo populacional realizado nos Estados Unidos analisou 0 efeito do consumo de açúcar refinado no valor calórico total da dieta de crianças com idade entre 2 e 5 anos. As análises foram estratificadas por faixa etária, 2 a 3 anos e 4 a 5 anos, e as crianças classificadas em 5 grupos de acordo com o percentual de participação do açúcar em suas dietas. O estudo evidenciou aumento significativo do total calórico da dieta das crianças mais jovens (mas não nos mais velhos) com o aumento do percentual de participação do açúcar na dieta (KRANZ et al 2005). Outro estudo americano investigou o efeito da participação do consumo total de açúcares na dieta (nesse caso somando açúcar refinado e açúcares intrínsecos) sobre o valor calórico total da dieta de crianças com 10 
anos de idade, não encontrando associações significativas (FARRIS 1998).

Cabe mencionar que 0 estudo da associação entre participação de açúcar (ou qualquer outro alimento) na dieta e valor calórico total da dieta, como ocorreu nos dois estudos americanos referidos acima, tem sido questionado, uma vez que o total de calorias aparece nos dois lados da equação da associação: como denominador da variável explanatória e como variável desfecho (FORSHEE and STOREY 2004).

Estudo prospectivo com duração de 12 meses realizado nos Estados Unidos identificou associação significativa entre consumo de refrigerante e ganho de peso entre adolescentes com idade entre nove e 14 anos. Os autores deste estudo consideraram que 0 provável mecanismo da associação estaria no aumento do valor calórico total da dieta determinado pelo consumo de refrigerantes, uma vez que o efeito do consumo desses produtos sobre o excesso de peso foi intensamente atenuado com o controle do valor calórico total da dieta (BERKEY 2004).

A associação positiva entre consumo de refrigerante e ganho de peso ou obesidade e, mesmo, síndrome metabólica 
principalmente entre crianças e adolescentes, tem sido evidenciada por estudos realizados nos Estados Unidos e Canadá (LUDWING et al 2001, DUBOIS et al 2007, EBBELING et al 2006, DHINGRA et al 2007).

Estudos brasileiros que avaliem diretamente 0 efeito do consumo de açúcar sobre o valor calórico total da dieta ou mesmo sobre o excesso de peso ou a obesidade são necessários para confirmar os resultados relatados no presente estudo a partir de aquisições domiciliares de alimentos. Entretanto, independentemente da necessidade de mais estudos, os resultados aqui encontrados corroboram as propostas internacionais (WHO 2003) e nacionais (MS 2006) que recomendam a redução populacional no consumo de açúcar refinado. 


\section{Referências bibliográficas}

1. Anderson GH. Sugars, sweetness, and food intake. Am J Clin Nutr 1995;62(suppl):195S-202S.

2. Anderson $\mathrm{GH}$, Woodend $\mathrm{D}$. Consumption of sugars and the regulatotion of short-term satiety and food intake. Am J Clin Nutr 2003; 78(suppl): 843S-9S.

3. Bermudez O.I., Tucker K.L. Trends in dietary patterns of Latin American populations. Caderno de Saúde Pública 2003; 19:S87-S99.

4. Becker W. Comparability of household and individual food consumption data - evidence from Sweden. Public Health Nutr 2001; 4(5B):1177-1182.

5. Berkey CS, Rockett HRH, Field AE, Gillman MW, Colditz GA. Sugar-added beverages and adolescent weight change. Obesity Res 2004; 12(5):778-88.

6. Dhingra $R$, Sullivan $L$, Jacques PF, Wang TJ, Fox CS, Meigs JB, D Agostino RB, Gaziano JM, Vasan RS. Soft drink consumption and risk of developing cardiometabolic risk factors and the metabolic syndrome in middle-aged adults in the community. Circulation. 2007; 116: 480-488. 
7. DiMeglio DP, Mattes RD. Liquid versus solid carbohydrate: effects on food intake and body weight. International Journal of Obesity 2000; 24: 794-800.

8. Drewnowski A, Bellisle F. Liquid calories, sugar, and body weight. Am J Clin Nutr 2007; 85:651-61.

9. Dubois L, Farmer A, Girard M, Peterson K. Regular sugarsweetened beverage consumption between meals increases risk of overweight among preschool-aged children. J Am Diet Assoc 2007; 107:924-934.

10. Ebbeling $\mathrm{CB}$, Feldman HA, Osganian SK, Chomitz VR Ellenbogen SJ, Ludwig DS. Effects of decreasing sugarsweetened beverage consumption on body weight in adolescents: a randomized, controlled pilot study. Pediatrics 2006; 117:673-680.

11. [FAO/WHO] Food and Agriculture Organization/World Health Organization. Carbohydrates in Human Nutrition. Report of a Joint FAO/WHO Expert Consultation. Geneva: WHO 1998.

12. Farris RP, Nicklas TA, Myers Leann, Berenson GS. Nutrient intake and food group consumption of 10 -year-olds by sugar intake level:the Bogalusa Heart Study. J American College of Nutr 1998; 17(6):579-585.

13. Forshee R.A. and Storey M.L. Controversy and Statistical Issues in the Use of Nutrient Densities in Assessing Diet Quality. American Society for Nutritional Sciences 2004; 27332737. 
14. [IBGE] Instituto Brasileiro de Geografia e Estatística. Tabela de composição de alimentos. $4^{a}$ ed. Rio de Janeiro: Fundação IBGE. [Estudo Nacional da Despesa Familiar - ENDEF] 1996.

15. [IOM] Institute of Medicine. Dietary Reference Intakes for Energy, Carbohydrate, fiber, Fat, Fatty Acids, Cholesterol, Protein, and Amino Acids, ch 6, pp 1-43. Washington, DC: National Academies Press 2002.

16. Kranz S, Smiciklas-Wright $H$, Siega-Riz A.M, Mitchell D. Adverse affect of high added sugar consumption on dietert intake in American preschoolers. J pedriatr 2005; 146:105-11.

17. Levy-Costa RB, Sichieri R, Pontes NS, Monteiro CA. Disponibilidade domiciliar de alimentos no Brasil: distribuição e evolução (1974 - 2003). Rev Saúde Pública 2005; 39(4):53040.

18. Ludwig DS. The glycemic index: physiological mechanisms relating to obesity, diabetes, and cardiovascular diseases. JAMA 2002; 287: 2414-23.

19. Ludwig DS, Peterson KE, Gortmaker SL. Relation between consumption of sugar-sweetened drinks and childhood obesity: a prospective, observational analysis. Lancet 2001; 357: 5058. 
20. Monteiro CA, Campino ACC, Passos DM, Machado FMS, Carmo HCE, Westphal MF, Jaime PC. Padrões de consumo alimentar no Brasil tendências, determinantes e proposição de ações de promoção da segurança alimentar do país. NUPENS/USP; 2006. (relatório técnico - Cnpq, abril/2006).

21. Monteiro CA, Mondini L, Levy-Costa RB. Mudanças na composição e adequação nutricional da dieta familiar nas áreas metropolitanas do Brasil (1988 - 1996). Rev Saúde Pública 2000; 34(3):251-8.

22. [MS] Ministério da Saude. Secretaria de Atenção à saúde. Departamento de atenção Básica. Coordenação-Geral da Política de Alimentação e Nutrição. Guia Alimentar para a População Brasileira: promovendo a alimentação saudável. Brasília 2006.

23. Naska A, Vasdekis VGS, Trichopoulou A. A preliminary assessment of the use of household budget survey data for the prediction of individual food consumption. Public Health Nutr 2001; 4(5B):1159-1165.

24. [NEPA/UNICAMP] Núcleo de Estudos e Pesquisas em Alimentação/Universidade Estadual de Campinas. Tabela Brasileira de Composição de Alimentos - TACO: versão 1. Campinas, São Paulo: NEPA/UNICAMP 2004.

25. Popkin B.M., Nielsen S.J. The Sweetening of the world's diet. Obesity research 2003; 11(11):1325-1332. 
26. Rajeshwari R., Su-Jau Y, Nicklas T.A., Berenson G.S. Secular trends in children's sweetened - beverafe consumption (1973 to 1994): the Bogalusa Heart Study. J Am Diet Assoc 2005; 105:208-214.

27. Rolls BJ, Bell EA. Dietary approaches to the treatment of obesity. Medical Clinics of North American 2000; 84: 401-18.

28. Stata Statistical/Data Analysis software: 8.0 Special Edition. College Station, Texas, USA 1984-2003: Stata Corporation.

29. Stubbs J, Ferres S, Horgan G. Energy density of foods: effects on energy intake. Critical Reviews in Food Science and Nutrition. 2000; 40:481:515.

30. [USDA] United States Department of Agriculture 2004. USDA Food Search for Windows, version 1.0, database version Standard Reference Release SR16. Agricultural Research Service (ARS). Software desenvolvido via acordo de cooperação em pesquisa e desenvolvimento pelo U.S. Department of Agriculture Nutrient Data Laboratory e Health Tech, Inc. Disponivel na Internet: <www.nal.usda.gov/fnic/foodcomp> [Data de Acesso: Março de 2006].

31. Van Wymelbeke V, Beridot-Therond ME, de La Gueronniere V, Fantino $M$. Influence of repeated consumption of beverages containing sucrose or intense sweeteners on food intake. Eur J Clin Nutr 2004; 58: 154-61. 
32. [WHO/FAO] World Health Organization/Food and Agriculture Organization Diet, Nutrition and the Prevention of Chronic Diseases Report of a Joint WHO / FAO Expert Consultation. WHO Technical Report series no. 916. Geneva:WHO 2003. 
4. ARTIGO 3

Efeito da aquisição de açúcar sobre - perfil em macronutrientes da disponibilidade domiciliar de alimentos (Brasil 2002-2003). 
Efeito da aquisição de açúcar sobre o perfil em macronutrientes da disponibilidade domiciliar de alimentos (Brasil 2002-2003)

\section{Resumo}

Objetivo: Estudar a influência que a aquisição de calorias provenientes de açúcar (açúcar de mesa ou açúcar presente em alimentos processados) exerce sobre a participação calórica dos demais macronutrientes na disponibilidade domiciliar de alimentos. Metodologia: Utilizaram-se dados sobre aquisição de alimentos coletados pela Pesquisa de Orçamentos Familiares - POF, realizada entre junho de 2002 e julho de 2003 pelo IBGE em uma amostra probabilística de 48.470 domicílios do país. As unidades de observação para este estudo correspondem a cada um dos 443 estratos amostrais da POF formados por conjuntos de domicílios pertencentes a setores censitários semelhantes quanto à localização geográfica e nível de escolaridade dos chefes de família. As quantidades dos alimentos que cada estrato de domicílios adquiriu ao longo de 12 meses foram transformadas em calorias utilizando tabelas de composição de alimentos. A influência das calorias provenientes de açúcar sobre a participação calórica de cada um dos demais macronutrientes na disponibilidade domiciliar de alimentos foi estudada por meio de modelos de regressão linear múltipla com ajuste para o valor calórico total da aquisição de 
alimentos, excetuadas as calorias provenientes do açúcar, e para variáveis sócio-demográficas. Resultados: Evidenciou-se que calorias adquiridas de açúcar aumentam significativamente a participação de gorduras na disponibilidade domiciliar de alimentos e diminuem, também significativamente, a participação de proteínas. Calorias de açúcar procedentes de alimentos processados aumentam significativamente a participação de gorduras e de ácidos graxos saturados e diminuem, também significativamente, a participação de outros carboidratos que não o açúcar. Conclusões: Os resultados encontrados neste estudo trazem novas evidências sobre o papel prejudicial do açúcar a saúde humana que corroboram orientações brasileiras e internacionais que recomendam a redução no consumo deste alimento e estipulam limites máximos para sua participação na dieta. 


\section{Introdução}

Dados de inquéritos nacionais, de base populacional, realizados no Brasil entre 1975 e 2003 evidenciam declínio continuo da prevalência de déficits ponderais e avanço alarmante da prevalência de excesso de peso e obesidade, em todas as regiões do País e em todas as classes de renda (IBGE 2004, IBGE 2006, MONTEIRO et al 2007).

Para estudiosos do fenômeno da transição nutricional nos países em desenvolvimento, a trajetória dos indicadores nutricionais descritos no Brasil se deve a mudanças na composição das dietas e no estilo de vida dos indivíduos decorrentes de mudanças no ambiente relacionadas à industrialização, urbanização e integração daqueles países à economia global (POPKIN 2002).

A evolução da disponibilidade de alimentos na América Latina indica tendência de aumento na participação de gorduras na dieta, principalmente gordura de origem animal, e aumento da já elevada participação de calorias de açúcar na dieta. Entre 1970/72 e 1995/96 a participação do açúcar na disponibilidade de alimentos dos países latinoamericanos aumentou de 15,8\% para $16,9 \%$ (BERMUDEZ and TUCKER 2003). No Brasil a evolução da 
disponibilidade nacional de alimentos entre 1961/63 e 1999/2001 aponta grande aumento na participação de gorduras (de 15,7\% para $26,3 \%$ das calorias totais) e aumento na já elevada participação de açúcar (de 18,0 para 18,8 das calorias totais) (MONTEIRO et al 2007 FAO 2004).

O acúmulo de evidências que indicam que determinadas características da dieta aumentam substancialmente o risco de doenças cardiovasculares, certos tipos de câncer, obesidade, dislipidemias e diabetes, entre outras, fez com que a OMS estabelecesse limite máximo de consumo para a ingestão de gorduras ( $30 \%$ do valor calórico total), ácidos graxos saturados ( $10 \%$ do consumo calórico total), colesterol (300 mg dia) e açúcar ( $10 \%$ do valor calórico total) e limites mínimos para o consumo de frutas e hortaliças ( $400 \mathrm{~g}$ por dia) e carboidratos complexos (entre 55 e $75 \%$ do valor calórico total) (WHO/FAO 2003).

Dados da Pesquisa de Orçamentos Familiares realizada no período 2002-2003 (POF 2002-2003) em amostra probabilística representativa do conjunto dos domicílios brasileiros evidenciaram que o limite máximo de $10 \%$ das calorias totais provenientes de açúcar recomendado pela Organização Mundial de Saúde - OMS 
era ultrapassado em todas as regiões do país (LEVY-COSTA et al 2005).

Embora a recomendação da OMS em limitar o consumo de açúcar não seja seguida por todos os países - nos EUA e Canadá, por exemplo, o limite superior para a participação do açúcar nas calorias totais é de $25 \%$ (IOM 2002) - ela encontra suporte em vários estudos que associam o consumo de açúcar a efeitos desfavoráveis para a saúde. Dentre esses efeitos destacam-se aumento na ocorrência de cárie dental (WHO/FAO 2003), ganho excessivo de peso (LUDWIG et al 2001, DUBOIS et al 2007) e aumento na incidência de doenças cardiovasculares (FRIED and RAO 2003) e diabetes (KELLEY 2003).

Há também evidências de que o consumo de açúcar influencia negativamente características gerais da dieta, contribuindo para o consumo excessivo de calorias (KRANZ et al 2005, POPKIN and NIELSEN 2003, MANN 2004), diminuindo a participação de outros macronutrientes (FARRIS 1998, KRANZ et al 2005) e diluindo a concentração de micronutrientes (POPKIN and NIELSEN 2003, KRANZ et al 2005, UTE et al 2002). 
Em estudo anterior, a partir de dados sobre aquisição domiciliar de alimentos coletados pela POF 2002-2003, evidenciamos que calorias adquiridas de açúcar levaram a aumentos substanciais no total de calorias adquiridas pelas famílias brasileiras (LEVY and MONTEIRO 2007 ( $2^{\circ}$ artigo desta tese)) No presente estudo examinaremos, a partir da mesma base de dados, a influência que a aquisição de calorias provenientes de açúcar (açúcar de mesa ou açúcar presente em alimentos processados) exerce sobre a participação calórica de cada um dos demais macronutrientes na disponibilidade domiciliar de alimentos. 


\section{Métodos}

Todos os dados utilizados neste estudo provêm da Pesquisa de Orçamentos Familiares realizada pelo Instituto Brasileiro de Geografia e Estatística no período de junho de 2002 a julho de 2003 (POF 2002-2003).

\section{Amostragem}

O desenho da amostra da POF 2002-2003 foi estruturado de modo a representar o conjunto dos domicílios brasileiros, bem como as cinco grandes regiões do país conforme situação urbana ou rural, os 26 estados brasileiros, as nove regiões metropolitanas e as capitais dos 26 estados no que se refere à situação urbana. Trata-se de uma amostra estratificada, sorteada em dois estágios. Os estratos, em número de 443 , foram formados, agrupando-se os setores censitários do país com base em critérios geográficos (estado, região e situação urbana ou rural do setor) e socioeconômicos (média de escolaridade do chefe do domicílio no setor, segundo o Censo Demográfico de 2000). O sorteio de setores censitários (unidade primária de amostragem) dentro de cada estrato foi feito por amostragem sistemática com probabilidade proporcional ao número de domicílios no setor. 0 
sorteio de domicílios (unidade secundária de amostragem) dentro de cada setor foi feito por amostragem aleatória simples, sem reposição. Os domicílios sorteados dentro de cada um dos 443 estratos foram distribuídos ao longo dos doze meses de duração da pesquisa, para que a coleta de dados fosse uniforme nos quatro trimestres do ano. Foram entrevistados 48.470 domicílios em 3.984 setores.

O período de referência utilizado pela POF 2002-2003 para a coleta de informações sobre aquisição de alimentos em cada domicílio é de apenas sete dias, o que não permite uma caracterização adequada do padrão de aquisição de alimentos de cada domicílio estudado. Por esta razão, na presente investigação, optou-se por adotar como unidade de estudo, não o domicílio individual estudado pela POF 2002-2003, mas o conjunto de domicílios existentes em cada um dos 443 estratos da amostra. 0 número médio de domicílios estudado dentro de cada um dos 443 estratos da POF 2002-2003 foi de 109,6, variando de 9 a 804 domicílios. O fator amostral de ponderação de cada estrato resultou da somatória dos fatores amostrais de ponderação dos domicílios pertencentes a cada estrato. 


\section{Coleta de dados}

As informações referentes aos alimentos adquiridos em cada domicílio foram obtidas utilizando a caderneta de despesa coletiva da pesquisa. Nesta caderneta são registradas todas as aquisições de alimentos feitas durante um período de sete dias consecutivos incluindo quantidade, unidade de medida com seu equivalente em peso ou volume, valor da despesa, local de compra e a forma de obtenção do alimento. Em cerca de $75 \%$ dos domicílios, os dados sobre aquisição de alimentos foram registrados em meio eletrônico, no próprio momento da coleta de dados, com a utilização de computadores portáteis o que possibilitou a verificação da consistência das informações e a correção de erros ainda no domicílio.

\section{Construção de variáveis}

As variáveis centrais desde estudo são representadas pelas quantidades de açúcar, de outros carboidratos que não o açúcar, de proteínas e de gorduras presentes nas aquisições de alimentos feitas pelos domicílios que constituem cada estrato da amostra da POF 2002-2003. Tanto no caso do açúcar quanto no caso dos demais macronutrientes, as quantidades adquiridas pelo estrato 
são expressas em kcal/per capita/dia. No caso das calorias provenientes de açúcar foram consideradas tanto o açúcar de mesa quanto os açúcares adicionados pela indústria aos alimentos processados. Rapadura, melado, mel e outros adoçantes calóricos, embora representem proporção diminuta do total de calorias adquiridas pelas famílias brasileiras, foram igualmente consideradas no cômputo do total de calorias provenientes de açúcar. Os açúcares intrínsecos, presentes naturalmente nos alimentos, como a frutose nas frutas e a lactose nos leites, foram considerados neste estudo como parte do restante dos carboidratos da alimentação. No caso das calorias provenientes de gorduras foram consideradas separadamente as calorias provenientes de ácidos graxos saturados.

Os procedimentos empregados para se chegar à aquisição diária per capita de cada macronutriente (expressa em kcal) em cada estrato de domicílios foram os seguintes: 1) soma das quantidades adquiridas de um mesmo alimento (em gramas) ao longo dos sete dias de coleta; 2) aplicação para cada alimento de fator de correção que leva em conta apenas as partes comestíveis dos alimentos (IBGE 1996); 3) conversão da quantidade adquirida de cada alimento em calorias de açúcar refinado e calorias dos demais macronutrientes de interesse, empregando-se para tanto a 
tabela TACO (Tabela Brasileira de Composição de Alimentos) (NEPA 2004) ou a tabela oficial de composição nutricional americana (USDA 2004), versão 15, quando o alimento não estava disponível na primeira tabela. 4) soma das calorias provenientes de cada macronutriente de interesse adquiridas pelos domicílios de um mesmo estrato e divisão do resultado pela soma do número de indivíduos no estrato (os fatores amostrais de ponderação de cada domicílio foram utilizados nesta etapa).

Atributos sócio-demográficos dos estratos de domicílios (unidades de estudo) foram utilizados para controlar possíveis variáveis de confusão para a associação entre calorias adquiridas de açúcar e calorias dos demais macronutrientes. Tais variáveis incluíram a macro região onde se situava o estrato de domicílios (Norte, Nordeste, Sudeste, Sul e Centro Oeste) e sua inserção em área urbana ou rural, além dos valores médios no estrato da renda domiciliar per capita e do percentual de menores de 20 anos, de maiores de 64 anos e de mulheres. Para se chegar aos valores médios dessas variáveis no estrato, foram empregados os fatores amostrais de ponderação dos domicílios pertencentes a cada estrato. 


\section{Análise dos dados}

O efeito da aquisição de açúcar sobre o perfil de macronutrientes na disponibilidade domiciliar de alimentos foi estudado a partir de modelos de regressão linear múltiplos específicos para cada macronutriente de interesse. A variável dependente desses modelos foi o total de calorias correspondente ao macronutriente e as variáveis explanatórias foram o total de calorias correspondente ao açúcar e o valor calórico total da aquisição de alimentos excetuadas as calorias do açúcar. Com a inclusão desta última variável nos modelos, o coeficiente de regressão do açúcar indica a influência que a quantidade adquirida de açúcar exerce sobre a quantidade adquirida do macronutriente independente de variações no valor calórico total de aquisição de alimentos (excetuadas as calorias do açúcar). Ou seja, nesta situação, o coeficiente de regressão do açúcar indica a participação relativa do macronutriente no valor calórico total da aquisição de alimentos excetuado o açúcar. Ademais, visando ao controle de potenciais variáveis de confusão para a relação entre aquisição de açúcar e a participação relativa de cada macronutriente na disponibilidade domiciliar de alimentos, adicionaram-se aos modelos de regressão múltipla as variáveis de caracterização sóciodemográfica das unidades de estudo (estratos de domicílios) que 
apresentaram valor $p$ inferior a 0,20 na associação bivariada com o macronutriente de interesse ou com o total de calorias do açúcar. A seguir, utilizando-se o procedimento "backward", foram retiradas dos modelos, uma a uma, as potenciais variáveis de confusão, iniciando pela variável com o maior valor $p$ e mantendo-se no modelo final todas as variáveis cuja retirada tivesse alterado em mais de $10 \%$ a magnitude do coeficiente de regressão do açúcar.

Procedimentos análogos de modelagem foram empregados para se estudar a influência específica do açúcar de mesa (somado a outros adoçantes calóricos empregados pelas famílias, como mel, melado e rapadura) e dos açúcares adicionados pela indústria a alimentos processados.

A adequação dos modelos finais de regressão foi realizada empregando-se análise de resíduos. Em todas as análises deste estudo, foram utilizados fatores amostrais de ponderação que permitem a extrapolação dos resultados para a população brasileira. Todas as análises foram feitas com o emprego do aplicativo estatístico Stata/SE versão 8.0 (STATA 2003). 


\section{Resultados}

A Tabela 1 mostra que a aquisição domiciliar de calorias provenientes de todos os macronutrientes aumenta de modo uniforme e significativo com o aumento das calorias provenientes de açúcar.

Tabela 1 - Valores médios para calorias provenientes de diferentes macronutrientes segundo quartis das calorias provenientes de açúcar na aquisição domiciliar de alimentos. Brasil, 2002/2003.

\begin{tabular}{c|cccc}
\hline $\begin{array}{c}\text { Quartis da aquisiçá } \\
\text { de açúcar }\end{array}$ & $\begin{array}{c}\text { Proteína* } \\
\text { (kcal/per } \\
\text { capita/dia) }\end{array}$ & $\begin{array}{c}\text { Carboidratos } \\
\text { exceto açúcar } \\
\text { refinado* } \\
\text { (kcal/per } \\
\text { capita/dia) }\end{array}$ & $\begin{array}{c}\text { Gorduras } \\
\text { totais* } \\
\text { (kcal/per } \\
\text { capita/dia) }\end{array}$ & $\begin{array}{c}\text { Ácidos graxos } \\
\text { saturados* } \\
\text { (kcal/per } \\
\text { capita/dia) }\end{array}$ \\
\hline $1^{\circ}(9,2-231,3)$ & 181,9 & 641,6 & 415,0 & 119,2 \\
$2^{\circ}(231,3-290,7)$ & 200,2 & 755,0 & 489,0 & 135,6 \\
$3^{\circ}(292,0-334,8)$ & 219,0 & 806,1 & 546,4 & 152,9 \\
$4^{\circ}(334,8-768,2)$ & 249,9 & 992,1 & 635,2 & 172,6 \\
\hline
\end{tabular}

${ }^{*} p<0,000$ para tendência linear

A Tabela 2 apresenta resultados dos modelos de regressão relativos à associação entre aquisição domiciliar de açúcar e aquisição de outros macronutrientes. Os coeficientes de regressão brutos confirmam e quantificam as associações positivas entre açúcar e cada um dos demais macronutrientes evidenciadas na tabela anterior. Os coeficientes ajustados para o valor calórico total de aquisição de alimentos (excetuadas as calorias do açúcar) indicam, por sua vez, que calorias de açúcar estão associadas a variações significativas na participação dos demais macronutrientes 
na disponibilidade domiciliar de alimentos. Calorias de açúcar determinam aumento na participação de gorduras e diminuição na participação de proteínas e de outros carboidratos que não açúcar.

Tabela 2 - Coeficientes de regressão das calorias provenientes de açúcar sobre as calorias provenientes de outros macronutrientes na aquisição domiciliar de alimentos. Brasil 2002-2003.

\begin{tabular}{l|cccc}
\hline $\begin{array}{c}\text { Variável dependente no modelo } \\
\text { (kcal/per capita/dia) }\end{array}$ & $\begin{array}{c}\text { Coeficientes } \\
\text { brutos } \\
\text { (kcal/per } \\
\text { capita/dia) }\end{array}$ & $\begin{array}{c}\text { Coeficientes } \\
\text { ajustados* } \\
\text { (kcal/per } \\
\text { capita/dia) }\end{array}$ & $\begin{array}{c}\text { IC } \\
\text { (k5\%dos coeficientes } \\
\text { ajustados }\end{array}$ \\
\hline Gorduras & 1,059 & 0,393 & 0,208 & 0,577 \\
Ácidos graxos saturados & 0,265 & 0,038 & $-0,030$ & 0,106 \\
Carboidratos exceto açúcar & 1,729 & $-0,224$ & $-0,442$ & $-0,006$ \\
Proteínas & 0,352 & $-0,067$ & $-0,122$ & $-0,011$ \\
\hline
\end{tabular}

*Ajustados para o total de calorias adquiridas excetuadas as do açúcar.

A Tabela 3 apresenta resultados de modelos de regressão múltipla relativos às associações entre calorias provenientes do açúcar e de suas frações (açúcar de mesa e açúcar presente em alimentos processados) e calorias provenientes de outros macronutrientes. Esses modelos são ajustados para o valor calórico total da aquisição de alimentos excetuadas as calorias de açúcar (ou de cada fração de açúcar) e, adicionalmente, para as variáveis sócio-demográficas que se mostraram variáveis de confusão para a associação entre calorias de açúcar (ou de suas frações) e calorias de cada macronutriente. 
Com o ajuste adicional para variáveis sócio-demográficas, os coeficientes de regressão indicam que calorias provenientes de açúcar determinam aumento significativo na participação relativa de gorduras e diminuição, também significativa na participação de proteínas.

Os resultados dos modelos de regressão relativos à influência das frações do açúcar sobre a participação relativa na disponibilidade domiciliar de alimentos dos demais macronutrientes indicam efeitos significativos apenas no caso do açúcar presente em alimentos processados. Calorias de açúcar presentes em alimentos processados determinam aumento significativo na participação de gorduras totais e de ácidos graxos saturados e diminuição, também significativa, na participação de carboidratos que não o açúcar. Calorias de açúcar de mesa determinam aumento na participação de gorduras totais que fica no limite da significância estatística $(p=0,058)$. 
Tabela 3 - Coeficientes de regressão ajustados das calorias provenientes de açúcar e suas frações sobre as calorias provenientes de outros macronutrientes na aquisição domiciliar de alimentos. Brasil 2002-2003.

\begin{tabular}{|c|c|c|c|}
\hline $\begin{array}{c}\text { Variável } \\
\text { dependente do } \\
\text { modelo }\end{array}$ & $\begin{array}{c}\text { Açúcar } \\
\text { (kcal/per capita/dia) }\end{array}$ & $\begin{array}{c}\text { Fração açúcar de } \\
\text { mesa } \\
\text { (kcal/per capita/dia) }\end{array}$ & $\begin{array}{c}\text { Fração açúcar } \\
\text { presente em } \\
\text { alimentos } \\
\text { processados } \\
\text { (kcal/per capita/dia) }\end{array}$ \\
\hline Gorduras totais & $\begin{array}{c}0,313^{\mathrm{a}} \\
(0,158-0,469)\end{array}$ & $\begin{array}{c}0,177^{a} \\
(-0,006-0,361)\end{array}$ & $\begin{array}{c}1,568^{9} \\
(1,241-1,895)\end{array}$ \\
\hline $\begin{array}{l}\text { Ácidos graxos } \\
\text { saturados }\end{array}$ & $\begin{array}{c}0,022^{b} \\
(-0,032-0,075)\end{array}$ & $\begin{array}{c}-0,019^{b} \\
(-0,074-0,036)\end{array}$ & $\begin{array}{c}0,436^{\mathrm{h}} \\
(0,303-0,570)\end{array}$ \\
\hline $\begin{array}{c}\text { Carboidratos exceto } \\
\text { açúcar }\end{array}$ & $\begin{array}{c}-0,155^{c} \\
(-0,319-0,010)\end{array}$ & $\begin{array}{c}0,044^{\mathrm{e}} \\
(-0,165-0,254)\end{array}$ & $\begin{array}{c}-0,813^{\mathrm{e}} \\
(-1,315--0,310)\end{array}$ \\
\hline Proteínas & $\begin{array}{c}-0,067^{\mathrm{d}} \\
(-0,122--0,011)\end{array}$ & $\begin{array}{c}-0,054^{f} \\
(-0,114-0,006)\end{array}$ & $\begin{array}{c}0,125^{\mathrm{e}} \\
(-0,083-0,334)\end{array}$ \\
\hline
\end{tabular}

Intervalo de confiança de $95 \%$ entre parentes

Todos os coeficientes estão ajustados para o total de calorias adquiridas excetuadas as do açúcar

a Ajuste adicional para região e renda

${ }^{b}$ Ajuste adicional para região, renda e percentual de menores de 20 anos

c Ajuste adicional para renda e percentual de menores de 20 anos

${ }^{d}$ Ajuste adicional para região e percentual de menores de 20 anos

e Ajuste adicional para área, região, renda e percentual de menores de 20 anos

${ }^{f}$ Ajuste adicional para área, região e percentual de menores de 20 anos

${ }^{9}$ Ajuste adicional para o percentual de menores de 20 anos

${ }^{\mathrm{h}}$ Ajuste adicional para renda 


\section{Discussão}

Em estudo anterior, com base em dados coletados por inquérito probabilístico sobre aquisição de alimentos realizado em 2002-2003 em amostra representativa do conjunto dos domicílios brasileiros, evidenciou-se associação positiva e significativa entre calorias adquiridas de açúcar e o valor calórico total da aquisição domiciliar de alimentos. No presente estudo, realizado com base no mesmo inquérito, evidenciou-se que aumentos nas calorias adquiridas de açúcar determinam que a disponibilidade domiciliar de alimentos tenha maior participação de gorduras e menor participação de proteínas. Com relação especificamente a aumentos nas calorias da fração de açúcar proveniente de alimentos processados, evidenciou-se maior participação de gorduras e de ácidos graxos saturados e menor participação de carboidratos que não o açúcar.

Duas limitações principais devem ser consideradas quando se utilizam dados sobre aquisição domiciliar de alimentos para se avaliar o padrão alimentar das famílias: a não consideração dos alimentos consumidos fora de casa e a proporção de alimentos adquiridos e não consumidos. No caso da POF 2002-2003, utilizada no presente estudo, soma-se às duas limitações anteriores o curto 
período (uma semana) de registro das aquisições de alimentos em cada domicílio.

A primeira limitação - não consideração dos alimentos consumidos fora de casa - deve ter impacto limitado sobre os resultados do presente estudo, uma vez que ele trata de relações entre alimentos adquiridos para consumo no domicílio. De qualquer forma, análises realizadas, separadamente, para os estratos de domicílios com percentual médio de gasto com alimentação fora do domicílio inferior a $10 \%$ (onde se assume que seja menos importante o consumo de alimentos fora do domicílio) revelam resultados semelhantes aos obtidos para a amostra total de estratos (resultados não mostrados).

Com relação aos alimentos adquiridos e não consumidos, é razoável supor, inicialmente, que isso ocorra com magnitude relevante apenas nos estratos de mais alta renda. Ainda assim, para que a relação indicada pelo presente estudo entre consumo de açúcar e consumo de outros macronutrientes fosse afetada pelo eventual "desperdício" de alimentos seria preciso que a proporção não consumida de açúcar fosse diferente da proporção não consumida dos demais alimentos. 
Para fazer face ao problema do curto período de registro das aquisições de alimentos de cada domicílio na POF, optou-se por eleger como unidade de estudo grupos de domicílios homogêneos quanto ao nível sócio-econômico e localização geográfica, garantindo-se com isso, ademais, a caracterização da aquisição de alimentos em cada unidade de estudo ao longo dos quatro trimestres do ano.

Apesar das limitações características das POF, dados sobre aquisições de alimentos fornecem informações com considerável concordância quando comparadas com resultados obtidos por meio de inquéritos individuais de consumo, sobretudo quando os indicadores utilizados focalizam medidas relativas e não absolutas (NASKA et al 2001, BECKER 2001).

Dois pontos fortes do presente estudo são a representatividade nacional da amostra de domicílios estudada e o controle estatístico de diversos atributos sócio-demográficos que poderiam atuar como fator de confusão para a associação entre calorias de açúcar e perfil de macronutrientes da aquisição domiciliar de alimentos. Ainda assim, com relação a este último aspecto, como em qualquer estudo observacional, não se pode 
descartar a possibilidade de existência de fatores de confusão não considerados em nossa análise.

São escassos os estudos publicados sobre a influência do açúcar na composição da dieta em macronutrientes. Dois estudos realizados com crianças americanas encontraram associação inversa entre consumo de açúcar e consumo de proteínas, de gorduras totais e de ácidos graxos saturados. Com relação à associação entre açúcar e carboidratos totais (inclusive o açúcar), os resultados encontrados nos dois estudos divergem entre si, tendo sido observada associação direta em um deles e inversa no outro (FARRIS 1998, KRANZ et al 2005). Em nenhum dos dois estudos, houve controle de variáveis sócio-demográficas. Além disso, os dois estudos estudam a associação entre açúcar e demais macronutrientes analisando a participação relativa dos mesmos no valor calórico total da dieta, procedimento que fere o princípio de independência entre as variáveis estudadas (FORSHEE and STOREY 2004).

Um terceiro estudo realizado com crianças e adolescentes na Alemanha identificou associação inversa entre consumo de açúcar e um escore de alimentação saudável, composto, entre outras variáveis, pelo percentual de participação de gorduras e de ácidos 
graxos saturados. A partir dos resultados deste estudo os autores sugerem como recomendação para a população de crianças e adolescentes alemãs limites entre $6 \%$ e $12 \%$ para a participação do açúcar no valor calórico total da dieta (UTE et al 2003).

A relação empírica encontrada neste estudo entre açúcar proveniente de alimentos processados e participação de gorduras totais e ácidos graxos saturados na disponibilidade domiciliar de alimentos poderia se dever a dois mecanismos. O primeiro mecanismo seria a presença simultânea (em grande proporção) de açúcar e gorduras nos alimentos processados. Este parece ser o caso de sorvetes, chocolates e biscoitos doces, produtos que representam $31,7 \%$ do total das calorias de açúcar nos alimentos processados adquiridos pelas famílias brasileiras. Em sorvetes e chocolates há entre $35 \%$ e $39 \%$ de calorias de açúcar e entre $48 \%$ e $51 \%$ de calorias de gorduras (sendo cerca de $60 \%$ provenientes de ácidos graxos saturados). Em biscoitos doces há cerca de $35 \%$ de calorias de açúcar e $25 \%$ de calorias de gorduras.

O segundo mecanismo para a associação entre açúcar proveniente de alimentos processados e participação de gorduras na disponibilidade domiciliar de alimentos envolveria eventuais associações entre aquisição de alimentos processados ricos em 
açúcar e aquisição de alimentos ricos em gorduras. A correlação positiva entre aquisição de refrigerantes, $(42,9 \%$ do total das calorias de açúcar nos alimentos processados adquiridos pelas famílias brasileiras), e a aquisição de doces, biscoitos e óleos e gorduras exemplifica bem este segundo mecanismo (coeficientes de correlação parcial, com ajuste para calorias totais, de 0,70 para doces, 0,28 para biscoitos e 0,24 para óleos e gorduras; todos com $p<0,001$ ) (dados não mostrados).

Independentemente dos mecanismos pelos quais a aquisição de açúcar (em geral e açúcar proveniente de alimentos processados) influencia 0 perfil de macronutriente da disponibilidade domiciliar de alimentos das famílias brasileiras, os resultados mostrados neste estudo trazem novas evidências sobre - papel prejudicial do açúcar para a saúde humana. Essas evidências corroboram orientações brasileiras (MS 2006) e internacionais (WHO/FAO 2003) que recomendam a redução no consumo de açúcar e estipulam limites máximos para sua participação na dieta. 


\section{Referências bibliográficas}

1. Becker W. Comparability of household and individual food consumption data - evidence from Sweden. Public Health Nutr 2001; 4(5B):1177-1182.

2. Bermudez O.I., Tucker K.L. Trends in dietary patterns of Latin American populations. Caderno de Saúde Pública 2003; 19: S87-S99.

3. Dubois L, Farmer A, Girard M, Peterson K. Regular sugarsweetened beverage consumption between meals increases risk of overweight among preschool-aged children. J Am Diet Assoc 2007; 107:924-934.

4. FAOSTAT. Food and Agriculture Organization Statistics Database. (2004). FAO Statistics database. Rome: Food and Agriculture Organization. Disponivel na Internet: $<$ http://faostat.fao.org/faostat/collections?version=ext\&hasbul $k=0>$ [Data de Acesso: Setembro de 2007].

5. Farris RP, Nicklas TA, Myers Leann, Berenson GS. Nutrient intake and food group consumption of 10 -year-olds by sugar intake level:the Bogalusa Heart Study. J American College of Nutr 1998; 17(6):579-585.

6. Forshee R.A. and Storey M.L. Controversy and Statistical Issues in the Use of Nutrient Densities in Assessing Diet Quality. American Society for Nutritional Sciences 2004; 27332737. 
7. Fried S.K., Rao S.P. Sugars, hypertriglyceridemia, and cardiovascular disease. American Journal of Clinic Nutrition $2003 ; 78(S): 873 S-880$ S.

8. [IBGE] Instituto Brasileiro de Geografia e Estatística. Pesquisa de Orçamentos Familiares 2002-2003: análise da disponibilidade domiciliar de alimentos e do estado nutricional no Brasil. Rio de Janeiro: IBGE; 2004.

9. [IBGE] Instituto Brasileiro de Geografia e Estatística. Pesquisa de Orçamentos Familiares 2002-2003: antropometria e análise do nutricional de crianças e adolescentes no Brasil. Rio de Janeiro: IBGE; 2006.

10. [IBGE] Instituto Brasileiro de Geografia e Estatística. Tabela de composição de alimentos. $4^{\text {a }}$ ed. Rio de Janeiro: Fundação IBGE. [Estudo Nacional da Despesa Familiar - ENDEF] 1996.

11. [IOM] Institute of Medicine. Dietary Reference Intakes for Energy, Carbohydrate, fiber, Fat, Fatty Acids, Cholesterol, Protein, and Amino Acids, ch 6, pp 1-43. Washington, DC: National Academies Press 2002.

12. Kelley D.E. Sugar and starch in the nutritional management of diabetes mellitus. American Journal of Clinical Nutrition 2003; 78(suppl):858S-864S.

13. Kranz S, Smiciklas-Wright H, Siega-Riz A.M, Mitchell D. Adverse affect of high added sugar consumption on diet intake in American preschoolers. J pedriatr 2005; 146:105-11. 
14. Ludwig DS, Peterson KE, Gortmaker SL. Relation between consumption of sugar-sweetened drinks and childhood obesity: a prospective, observational analysis. Lancet 2001; 357: 5058.

15. Levy-Costa RB, Sichieri R, Pontes NS, Monteiro CA. Disponibilidade domiciliar de alimentos no Brasil: distribuição e evolução (1974 - 2003). Rev Saúde Pública 2005; 39(4):53040.

16. Mann J. Free sugars and human health: sufficient evidence for action? Lancet 2004; 363:1068-1070.

17. Monteiro CA, Conde WL, Popkin BM. Income-specific shifts in obesity in Brazil: 1975 - 2003. Am J Public Health 2007; 97(10). (in press).

18. [MS] Ministério da Saude. Secretaria de Atenção à saúde. Departamento de atenção Básica. Coordenação-Geral da Política de Alimentação e Nutrição. Guia Alimentar para a População Brasileira: promovendo a alimentação saudável. Brasília 2006.

19. Naska A, Vasdekis VGS, Trichopoulou A. A preliminary assessment of the use of household budget survey data for the prediction of individual food consumption. Public Health Nutr 2001; 4(5B):1159-1165. 
20. [NEPA/UNICAMP] Núcleo de Estudos e Pesquisas em Alimentação/Universidade Estadual de Campinas. Tabela Brasileira de Composição de Alimentos - TACO: versão 1. Campinas, São Paulo: NEPA/UNICAMP 2004.

21. Popkin BM, Nielsen SJ. The Sweetening of the world's diet. Obesity research 2003; 11(11):1325-1332.

22. Popkin BM. Part II. What is unique about the experience in lower- and middle-income less-industrialized countries compared with the very-high-income industrialized countries? The shift in stages of the nutrition transition in the developing world differs from past experiences! Public Health Nutrition. 2002; 5(1A): 205-214.

23. Stata Statistical/Data Analysis software: 8.0 Special Edition. College Station, Texas, USA 1984-2003: Stata Corporation.

24. [USDA] United States Department of Agriculture 2004. USDA Food Search for Windows, version 1.0, database version Standard Reference Release SR16. Agricultural Research Service (ARS). Software desenvolvido via acordo de cooperação em pesquisa e desenvolvimento pelo U.S. Department of Agriculture Nutrient Data Laboratory e Health Tech, Inc. Disponivel na Internet: $<$ www.nal.usda.gov/fnic/foodcomp > [Data de Acesso: Março de 2006]. 
25. Ute A, Kersting M, Schultze-Pawlitscko V. Two approaches to derive a proposal for added sugars intake for German children and adolescents. Public Health Nutrition. 2003; 6(7): 697-702.

26. Ute $\mathrm{A}$, Wolfgang $\mathrm{SH}$, Kersting $\mathrm{M}$. Fortification masks nutrient dilution due to added sugars in the diet of children and adolescents. J Nutr. 2002; 132: 2785-2791.

27. [WHO/FAO] World Health Organization/Food and Agriculture Organization Diet, Nutrition and the Prevention of Chronic Diseases Report of a Joint WHO / FAO Expert Consultation. WHO Technical Report series no. 916. Geneva:WHO 2003. 


\section{CONSIDERAÇÕES FINAIS}

O Brasil tem realizado POFs com alguma regularidade e por meio delas têm sido possível avaliar tendências seculares de disponibilidade domiciliar de alimentos nas áreas metropolitanas do País (MONDINI and MONTEIRO 1994, MONTEIRO et al 2000). Embora não permitam a avaliação direta do consumo alimentar das famílias, mas tão somente a disponibilidade de alimentos para consumo no domicilio, as POFs constituem fonte valiosa para obtenção de informação acerca do padrão de alimentação de uma população.

Com base na Pesquisa de Orçamentos Familiares realizada pelo IBGE em 2002-2003 em amostra probabilística representativa de todas as regiões do país, o primeiro artigo desta tese descreve o padrão de compra de alimento da população brasileira. Destacamse como características positivas, encontradas em todas as regiões e todas as classes de renda a adequação do teor protéico e o elevado aporte de proteínas de origem animal. Notam-se como características negativas a disponibilidade insuficiente de frutas e hortaliças e o excesso de açúcar refinado, ambos também disseminados no País. Nas regiões economicamente mais desenvolvidas e nos estratos de maior renda evidenciou-se 
participação excessiva de gorduras totais e de gorduras saturadas. A evolução do padrão de aquisição de alimentos entre 1975 e 2003 nas áreas metropolitanas indica declínio do consumo de alimentos básicos, aumento do consumo de alimentos processados, como refrigerantes, biscoitos e embutidos, persistência de consumo excessivo de açúcar e insuficiente de frutas e hortaliças e aumento do teor de gorduras totais e gorduras saturadas na dieta.

O segundo artigo desta tese evidenciou associação positiva e significativa entre aquisição de calorias provenientes de açúcar e o valor calórico total da aquisição domiciliar de alimentos. Evidenciou, também, que na condição de ausência de despesas com alimentação fora de casa, e, portanto, em um cenário em que a aquisição domiciliar de alimentos tenderia a se aproximar do consumo real dos indivíduos, a aquisição de açúcar levaria a aquisição total de calorias a valores claramente excessivos diante da ingestão de $2000 \mathrm{kcal} / \mathrm{dia}$ recomendadas para a população brasileira (MS 2006).

Finalmente, o terceiro artigo desta tese evidenciou que aumentos nas calorias adquiridas de açúcar determinam mudanças significativas no perfil em macronutrientes da disponibilidade domiciliar de alimentos: maior participação de gorduras e menor 
participação de proteínas. Com relação especificamente a aumentos nas calorias da fração de açúcar proveniente de alimentos processados, evidenciou-se maior participação de gorduras e de ácidos graxos saturados e menor participação de carboidratos que não o açúcar.

Em conclusão, os padrões e tendências da disponibilidade domiciliar de alimentos no Brasil são consistentes com a importância crescente de doenças crônicas não transmissíveis no perfil de morbi-mortalidade e com o aumento continuo da prevalência de obesidade no País enquanto os resultados relativos à influência do açúcar sobre o valor calórico total e o perfil em macronutrientes da disponibilidade domiciliar de alimentos corroboram orientações brasileiras e internacionais que recomendam a redução do consumo deste alimento e estipulam limites máximos para sua participação na dieta. 


\section{REFERÊNCIAS BIBLIOGRÁFICAS}

1. Bermudez O.I., Tucker K.L. Trends in dietary patterns of Latin American populations. Caderno de Saúde Pública 2003; 19: S87-S99.

2. Dubois L, Farmer A, Girard M, Peterson K. Regular sugarsweetened beverage consumption between meals increases risk of overweight among preschool-aged children. J Am Diet Assoc 2007; 107:924-934.

3. FAOSTAT. Food and Agriculture Organization Statistics Database. (2004). FAO Statistics database. Rome: Food and Agriculture Organization. Disponível na Internet: $<$ http://faostat.fao.org/faostat/collections?version=ext\&hasbul $k=0>$ [Data de Acesso: Setembro de 2007].

4. Farris RP, Nicklas TA, Myers Leann, Berenson GS. Nutrient intake and food group consumption of 10-year-olds by sugar intake level:the Bogalusa Heart Study. J American College of Nutr 1998; 17(6):579-585.

5. Fried S.K., Rao S.P. Sugars, hypertriglyceridemia, and cardiovascular disease. American Journal of Clinic Nutrition 2003;78(S):873S-880S.

6. [IBGE] Instituto Brasileiro de Geografia e Estatística. Pesquisa de Orçamentos Familiares 2002-2003: análise da disponibilidade domiciliar de alimentos e do estado nutricional no Brasil. Rio de Janeiro: IBGE; 2004. 
7. [IBGE] Instituto Brasileiro de Geografia e Estatística. Pesquisa de Orçamentos Familiares 2002-2003: antropometria e análise do nutricional de crianças e adolescentes no Brasil. Rio de Janeiro: IBGE; 2006.

8. [IOM] Institute of Medicine. Dietary Reference Intakes for Energy, Carbohydrate, fiber, Fat, Fatty Acids, Cholesterol, Protein, and Amino Acids, ch 6, pp 1-43. Washington, DC: National Academies Press 2002.

9. Kelley D.E. Sugar and starch in the nutritional management of diabetes mellitus. American Journal of Clinical Nutrition 2003; 78(suppl):858S-864S.

10. Kranz S, Smiciklas-Wright H, Siega-Riz A.M, Mitchell D. Adverse affect of high added sugar consumption on diet intake in American preschoolers. J pedriatr 2005; 146:105-11.

11. Ludwig DS, Peterson KE, Gortmaker SL. Relation between consumption of sugar-sweetened drinks and childhood obesity: a prospective, observational analysis. Lancet 2001; 357: 5058.

12. Malta DC, Cezário AC, Moura L, Morais Neto OL, Silva Jr JB. Construção da vigilância e prevenção das doenças crônicas não transmissíveis no contexto do Sistema Único de Saúde. Epidemiologia e Serviços de Saúde 2006; 15(3): 47-64.

13. Mann J. Free sugars and human health: sufficient evidence for action? Lancet 2004; 363:1068-1070. 
14. Monteiro CA, Conde $W L$, Popkin BM. Income-specific shifts in obesity in Brazil: 1975 - 2003. Am J Public Health 2007; 97(10). (in press).

15. Monteiro C.A., Mondini L., Levy-Costa R.B. Mudanças na composição e adequação nutricional da dieta familiar nas áreas metropolitanas do Brasil (1988-1996). Revista de Saúde Pública 2000;34(3):251-258.

16. Popkin BM, Nielsen SJ. The Sweetening of the world's diet. Obesity research 2003; 11(11):1325-1332.

17. Popkin BM. Part II. What is unique about the experience in lower- and middle-income less-industrialized countries compared with the very-high-income industrialized countries? The shift in stages of the nutrition transition in the developing world differs from past experiences! Public Health Nutrition. 2002; 5(1A): 205-214.

18. Ute $\mathrm{A}$, Wolfgang $\mathrm{SH}$, Kersting $\mathrm{M}$. Fortification masks nutrient dilution due to added sugars in the diet of children and adolescents. J Nutr. 2002; 132: 2785-2791.

19. [WHO/FAO] World Health Organization/Food and Agriculture Organization Diet, Nutrition and the Prevention of Chronic Diseases Report of a Joint WHO / FAO Expert Consultation. WHO Technical Report series no. 916. Geneva: WHO 2003. 